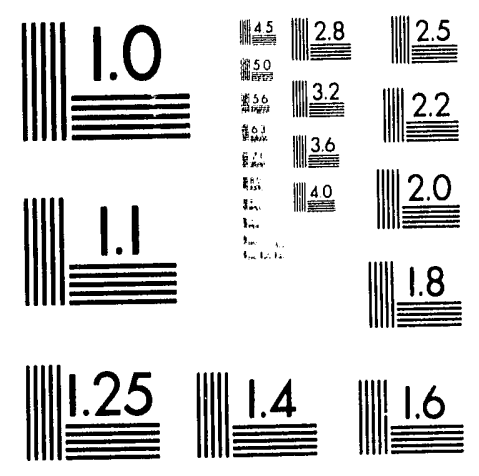



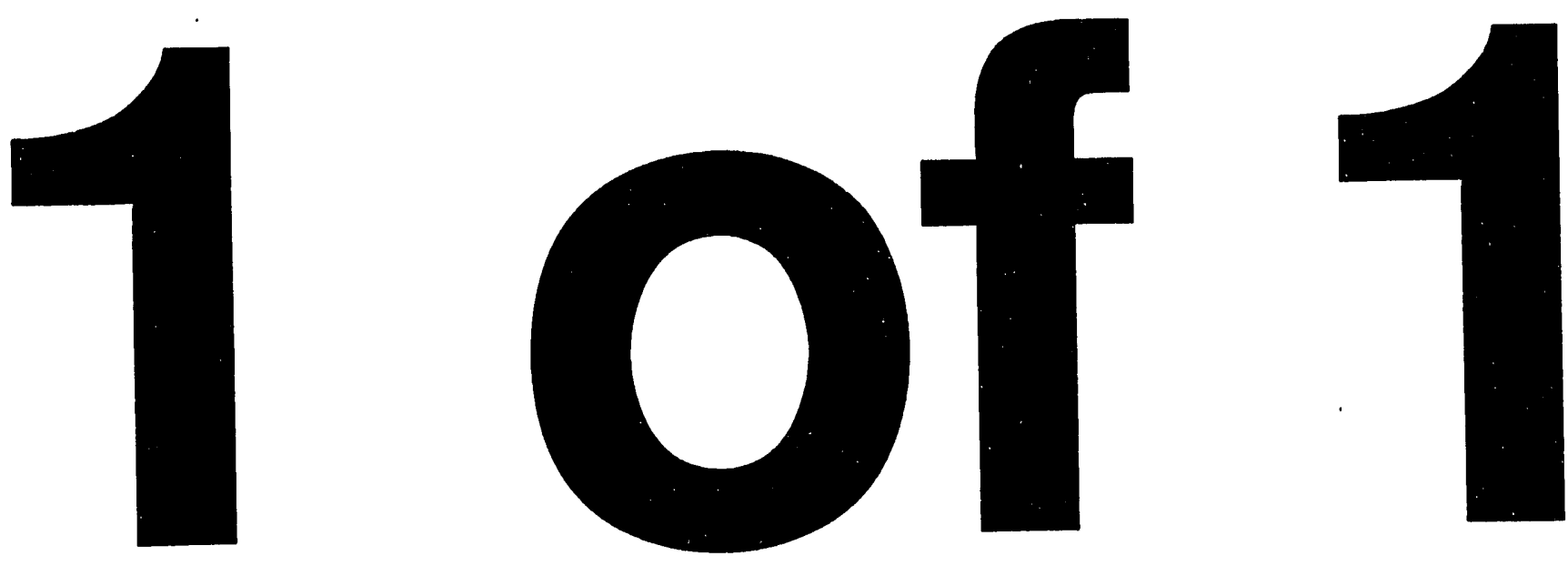
ARGONNE NATIONAL LABORATORY

9700 South Cass Avenue, Argonne, Illinois 60439

\title{
Preliminary Assessment Report for Fort Jacob F. Wolters, Installation 48555, \\ Mineral Wells, Texas
}

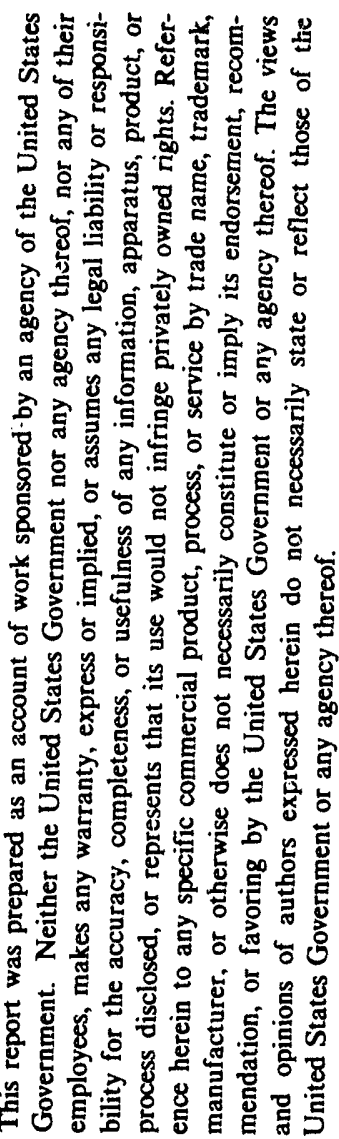

\author{
Prepared for \\ National Guard Bureau, Army Directorate \\ Aberdeen, Maryland
}

August 1993

\author{
Prepared by \\ Applied Geosciences and Environmental Management Section \\ Environmental Research Division \\ Argonne National Laboratory
}




\begin{tabular}{|c|c|c|c|}
\hline \multicolumn{2}{|c|}{ REPORT DOCUMENTATION PAGE } & \multicolumn{2}{|c|}{$\begin{array}{l}\text { FORM APPROVED } \\
\text { OMB No. } 0704-0188\end{array}$} \\
\hline \multicolumn{4}{|c|}{$\begin{array}{l}\text { Public reporting burden for this collection of information is estimated to average } 1 \text { hour per response, including } \\
\text { the time for reviewing instructions, searching existing data sources, gathering and maintaining the data needed, } \\
\text { and completing and reviewing the collection of information. Send comments regarding this burden estimate or } \\
\text { any other aspect of this collection of information, including suggestions for reducing this burden to Washington } \\
\text { Headquarters Services, Directorate for Information Operations and Reports, } 1215 \text { Jefferson Davis Highway, } \\
\text { Suite } 1204 \text {, Arlington, VA 22202-4302 and to the Office of Management and Budget, Paperwork Reduction } \\
\text { Project (0704-01880), Washington, DC } 20503 \text {. }\end{array}$} \\
\hline $\begin{array}{l}\text { 1. AGENCY USE ONLY } \\
\text { (Leave Blank) }\end{array}$ & $\begin{array}{l}\text { 2. REPORT DATE } \\
\text { August } 1993\end{array}$ & $\begin{array}{l}\text { 3. REPORT TYPE AND I } \\
\text { Preliminary site visit to }\end{array}$ & $\begin{array}{l}\text { DATES COVERED } \\
\text { complete assessment. }\end{array}$ \\
\hline \multicolumn{3}{|c|}{$\begin{array}{l}\text { 4. TITLE AND SUBTITLE } \\
\text { Preliminary Assessment Report for Fort Jacob F. Wolters, Installation } 48555 \text {, } \\
\text { Mineral Wells, Texas }\end{array}$} & $\begin{array}{l}\text { 5. FUNDING NUMBERS } \\
\text { MIPR-3788 }\end{array}$ \\
\hline \multicolumn{3}{|c|}{$\begin{array}{l}\text { 6. AUTHOR(S) } \\
\text { Clyde B. Dennis }\end{array}$} & MIPR-4188 \\
\hline \multicolumn{3}{|c|}{$\begin{array}{l}\text { 7. PERFORMING ORGANIZATION NAME(S) AND ADDRESS(ES) } \\
\text { Candace M. Rose } \\
\text { Argonne National Laboratory } \\
9700 \text { South Cass Avenue } \\
\text { Argonne, IL } 60439\end{array}$} & $\begin{array}{l}\text { 8. PERFORMING } \\
\text { ORGANIZATION } \\
\text { REPORT NUMBER } \\
\quad \text { None }\end{array}$ \\
\hline \multicolumn{3}{|c|}{$\begin{array}{l}\text { 9. SPONSORING/MONITORING AGENCY NAME(S) AND ADDRESS(ES) } \\
\text { National Guard Bureau } \\
\text { Army Directorate } \\
\text { Aberdeen, MD 21010-5420 }\end{array}$} & $\begin{array}{l}\text { 10. SPONSORING/ } \\
\text { MONITORING AGENCY } \\
\text { REPORT NUMBER } \\
\text { IR-CR-93087 }\end{array}$ \\
\hline \multicolumn{4}{|l|}{ None. } \\
\hline & $\begin{array}{l}\text { 12b. DISTRIBUTION } \\
\text { CODE }\end{array}$ \\
\hline \multicolumn{4}{|c|}{ This report addresses the information necessary to complete the PA. } \\
\hline \multirow{2}{*}{\multicolumn{3}{|c|}{ 14. SUBJECT TERMS }} & $\begin{array}{l}\text { 15. NUMBER OF PAGES } \\
\text { PA-76 }\end{array}$ \\
\hline & & & 16. PRICE CODE \\
\hline $\begin{array}{l}\text { 17. SECURITY } \\
\text { CLASSIFICATION OF } \\
\text { REPORT } \\
\quad \text { Unclassified }\end{array}$ & $\begin{array}{l}\text { 18. SECURITY } \\
\text { CLASSIFICATION OF } \\
\text { THIS REPORT } \\
\quad \text { Unclassified }\end{array}$ & $\begin{array}{l}\text { 19. SECURITY } \\
\text { CLASSIFICATION OF } \\
\text { ABSTRACT } \\
\quad \text { Unclassified }\end{array}$ & $\begin{array}{l}\text { 20. LIMITATION OF } \\
\text { ABSTRACT }\end{array}$ \\
\hline
\end{tabular}




\section{Contents}

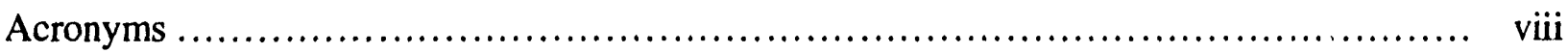

Summary .............................................................. 1

1 Introduction ............................................................ 5

1.1 Authority for the Preliminary Assessment $\ldots \ldots \ldots \ldots \ldots \ldots \ldots \ldots \ldots \ldots \ldots \ldots \ldots \ldots$

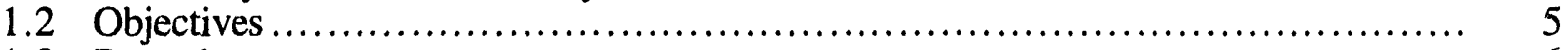

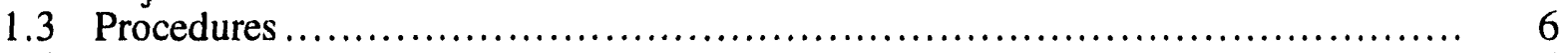

1.4 Report Format ........................................................ 6

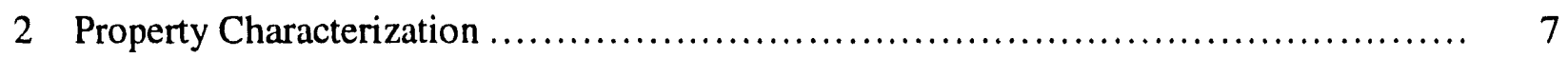

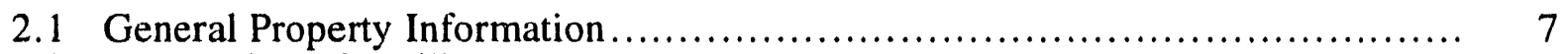

2.2 Description of Facilities ........................................................ 7

2.2.1 Unit Training Equipment Site 2 . . ..................................... 9

2.2.2 Exercise Area Maintenance Facility ................................. 13

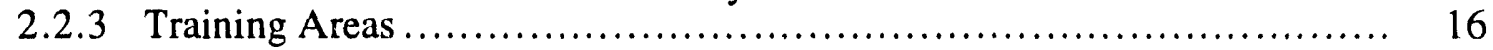

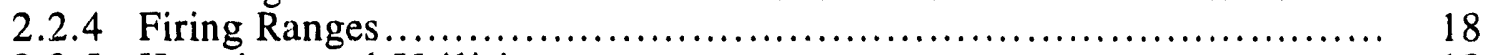

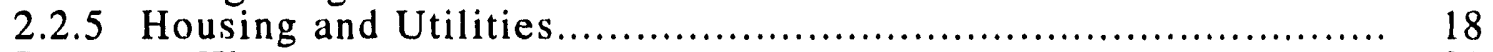

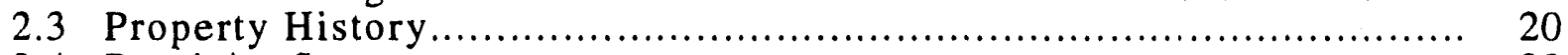

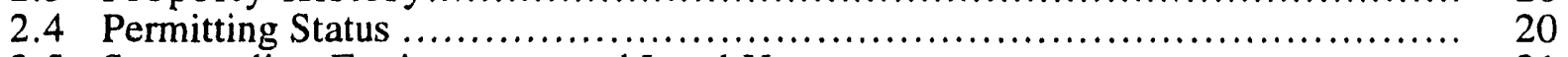

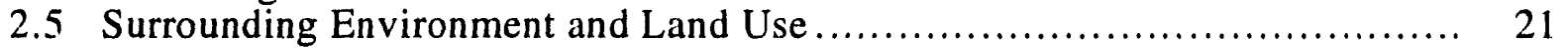

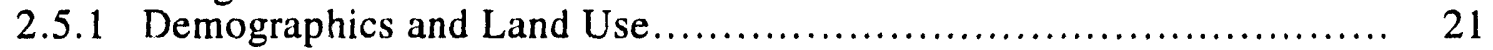

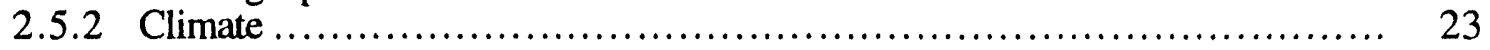

2.5.3 Surface Water and Physiography .................................... 23

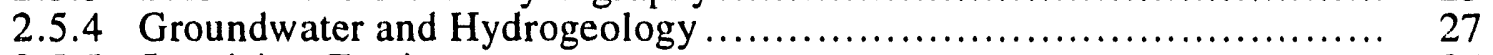

2.5.5 Sensitive Environments ............................................ 37

3 Environmentally Significant Operations ................................... 39

3.1 Fuel Storage and Dispensing ...................................... 39

3.2 Storage of Hazardous Materials/Hazardous Waste............................ 39

3.3 Former Nike Missile Program Operations ................................... 40

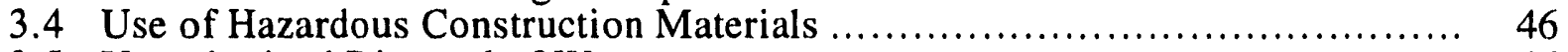

3.5 Unauthorized Disposal of Waste............................................ 46

4 Known and Suspected Releases ......................................... 48

4.1 Releases to Groundwater ................................................ 48

4.2 Releases to Surface Water ................................................ 48

4.3 Releases to Soil ........................................................ 49

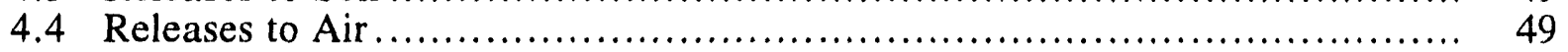

4.5 Other Releases ......................................................... 53

5 Human and Environmental Receptors........................................ 54

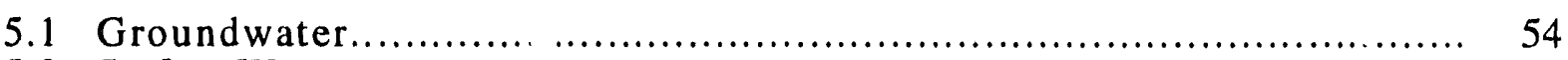

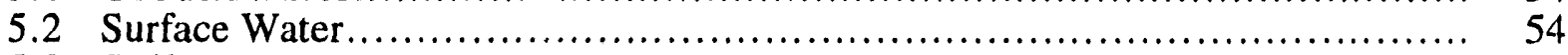

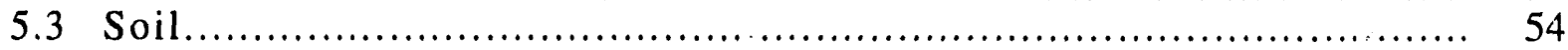




\section{Contents (Cont.)}

5.4 Air............................................................................... 55

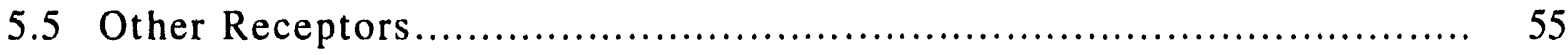

6 Preliminary Assessment Findings and Conclusions ............................. 56

6.1 Summary of Preliminary Assessment Findings ............................. 56

6.2 Recommendations for Further Action ...................................... 57

6.2.1 Fuel Storage and Dispensing .................................... 57

6.2.2 Storage and Use of Hazardous Materials............................. 57

6.2.3 Vehicle/Equipment Washing ......................................... 58

6.2.4 Former Nike Missile Base Operations............................. 58

6.2.5 Use of Hazardous Construction Materials ............................ 58

6.2.6 Unauthorized Disposal of Waste........................................ 59

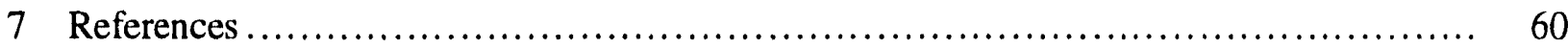

Appendix: Interview Information .................................................. 65

Figures

1 General Location of Fort Wolters............................................ 8

2 Location of Fort Wolters Training Areas and Activities................................ 10

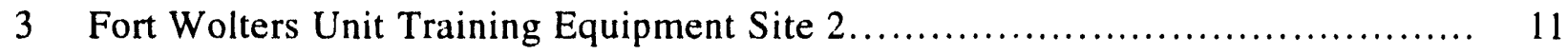

4 Fort Wolters Exercise Area Maintenance Facility .............................. 14

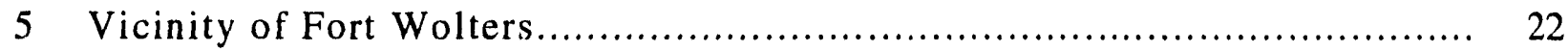

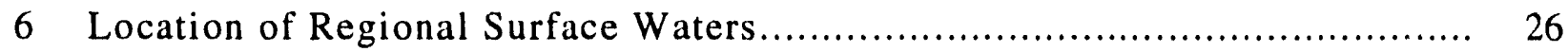

7 Cross Section of the Paleozoic Stratigraphic Units....................................... 29

8 Cross Section of the Cretaceous Sediments............................................... 31

9 Conceptual Diagram of Surface Discharge from the Regional Deep-Basin Brine Aquifer System................................................... 33

10 Locations of Water Wells in the Vicinity of Fort Wolters ....................... 35

11 Approximate Locations of Unauthorized Waste Disposal Areas......................... 47 


\section{Tables}

1 Identifying Information for Fort Wolters .....................................

2 Firing Ranges at Fort Wolters.............................................. 18

3 Ammunition Stored at Fort Wolters ............................................. 19

4 Driller's Log of Well UP-32-01-709....................................... 30

$5 \quad$ Water Wells in the Vicinity of Fort Wolters ................................... 37

6 Summary of Fuel Storage Tanks at Fort Wolters.............................. 40

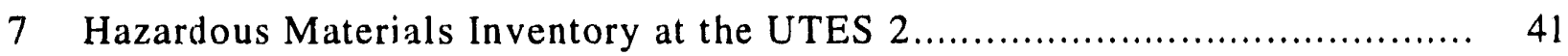

8 Hazardous Materials Inventory at the Exercise Area Maintenance Facility............ 42

9 Inventory of Hazardous Materials at Former Nike Facilities ........................ 44

10 Summary of Transformers at Fort Wolters ................................... 50

11 Samples of Building Construction Materials Collected Containing Asbestos ........ 51 


\section{Acronyms}

ACM

CERCLA

DHUD

EPA

ESE

ESO

FISP

HIPAR

IFC

IRFNA

IRP

MLA

NGB

PA

PCB

POL

RCRA

$\mathrm{TDH}$

TWC

TXARNG

UDMH

USACE

USAEC

USATHAMA

USGS

UST

UTES asbestos-containing material

Comprehensive Environmental Response, Compensation, and Liability Act

U.S. Department of Housing and Urban Development

U.S. Environmental Protection Agency

Environmental Science and Engineering, Inc.

environmentally significant operation

Facility Inventory and Stationing Plan

High-Power Acquisition Radar

Integrated Fire Control

inhibited red fuming nitric acid

Installation Restoration Program

Missile Launch Area

National Guard Bureau

preliminary assessment

polychlorinated biphenyl

petroleum, oils, and lubricants

Resource Conservation and Recovery Act

Texas Department of Health

Texas Water Commission

Texas Army National Guard

unsymmetrical dimethylhydrazone

U.S. Army Corps of Engineers

U.S. Army Environmental Center (formerly USATHAMA)

U.S. Army Toxic and Hazardous Materials Agency (now USAEC)

U.S. Geological Survey

underground storage tank

Unit Training Equipment Site 


\section{Preliminary Assessment Report for \\ Fort Jacob F. Wolters, Installation 48555, Mineral Wells, Texas}

\section{Summary}

This report presents the results of the preliminary assessment (PA) conducted by Argonne National Laboratory at the Texas Army National Guard (TXARNG) property near Mineral Wells, Texas. Preliminary assessments of federal facilities are being conducted to compile the information necessary for completing preremedial activities and to provide a basis for establishing corrective actions in response to releases of hazardous substances. The principal objective of the PA is to characterize the site accurately and determine the need for further action by examining site activities, quantities of hazardous substances present, and potential pathways by which contamination could affect public health and the environment. This PA satisfies, for the Fort Wolters property, the requirement of the Department of Defense Installation Restoration Program.

Fort Wolters, presently comprising 3,985 acres, is located near Mineral Wells, Texas, which is in Palo Pinto County. The majority of the TXARNG property extends eastward into Parker County. Fort Wolters has a long history of military operations dating from 1925. During World War II, it was the location of a large Infantry Replacement Center for the War Department, occupying 7,500 acres. After World War II, Fort Wolters became a U.S. Army helicopter training center. In the 1960s, Fort Wolters was the site of a Nike-Hercules Missile Program missile launch area and integrated fire control area. Throughout the Vietnam Conflict, it was the location of the nation's largest helicopter training base. In 1975, ownership of much of the reservation was transferred to state and local agencies.

The facility is the primary training area for two tank battalions, an armored cavalry squadron, and a forward support battalion. Fort Wolters is used for training in basic infantry skills, maneuver exercises, engineer skills, maintenance, helicopter operations, and use of firearms. It is also used extensively for aerial drop training by the Texas Air National Guard and the active U.S. Air Force. Organizational maintenance support is available through the Unit Training Equipment Site 2 (UTES 2). Facilities are available to house approximately 500 personnel. 
Maintenance activities performed at the Fort Wolters property as part of TXARNG operations require the use of hazardous materials and could result in the release of hazardous waste. In addition, hazardous waste could be present on the property as a result of the former Nike missile base operations, or in the form of original construction materials, or as a result of unauthorized disposal of waste on the property. Environmentally significant operations associated with the property are the following: (1) fuel storage and dispensing, (2) storage of hazardous materials/hazardous waste, (3) vehicle/equipment washing, (4) former Nike missile base operations, (5) the use of hazardous construction materials, and (6) unauthorized disposal of waste on the property. The review of both historical and current practices at the property indicated that the Fort Wolters TXARNG property poses low potential risk to human health and the environment.

Groundwater is not a significant source of drinking water in the area, although a few domestic wells are located within the 4-mi radius of concern. Fuel represents the highest volume of hazardous materials present on site. The central fueling area is near a 14,000-gal aboveground storage tank located within a concrete containing basin that prevents contaminant migration via the groundwater or surface water pathways. Older underground storage tanks, including those dating from the former Nike missile base operations, have been removed. Maintenance and fueling operations at the former missile launch area could have resulted in subsurface contamination, especially at the location of the former waste acid pit, into which waste acid or solvent cleaning solutions were discarded. Limited subsurface soil sampling at the location of the former waste acid pit is recommended to confirm that residual subsurface contamination is not present. Water sampling already performed within the abandoned missile silos indicates that no contamination is present at those locations.

Surface water from Lake Mineral Wells, located south of Fort Wolters, is the primary source of drinking water in the vicinity of Fort Wolters. Drainage from maintenance work areas is directed through oil-water separators before it enters the sanitary sewer system. Storage facilities for hazardous materials/hazardous wastes are largely adequate, preventing migration of contaminants via the surface water pathway. Installation of a small curb (or lip) at the door of the UTES 2 battery storage room is recommended to ensure containment in the event of a release there. The tank/vehicle wash facility at the UTES 2 is designed to prevent release of waste washwater and potential contaminants. If the tank wash area at the former UTES facility (the exercise area maintenance facility) is to be used frequently, upgrading of the washrack by the addition of an oil-water separator and drainage control is recommended. 
Two unauthorized waste disposal areas on the TXARNG property are located within surface drainage pathways feeding Lake Mineral Wells. The disposal area in the northern portion of the TXARNG property contains household-type waste and probably results from trespassing civilians. Cleanup of that small disposal area is recommended primarily to discourage continued trespassing on the property. No health hazard or risk to Lake Mineral Wells is suspected. The second, much larger disposal area contains metal debris and other waste strewn over an area approximately $300 \mathrm{ft}$ long and $10 \mathrm{ft}$ wide (as estimated from the air, where the view of the disposal area is partially obscured by vegetation). Close inspection of the disposal area is recommended to characterize the waste content. If the waste is determined to be hazardous in nature (for example, with containers or drums for chemicals or petroleum products), sampling within the disposal area and along the downgradient drainage pathway is recommended. The objective of this limited soil and water sampling effort would be to determine whether contamination is present at a level that would place the downgradient surface water resources at risk.

Surveys have confirmed the presence of polychlorinated biphenyls (PCBs) in transformers on the site and asbestos-containing construction materials in some buildings. The transformers have been catalogued with respect to PCB concentration and are monitored by the responsible electric company. To ensure the health of site workers, the only building in which asbestos was characterized as being friable is no longer used; abatement measures were recommended in an asbestos survey conducted in 1993. 


\section{Introduction}

This document is a report of the preliminary assessment (PA) conducted by Argonne National Laboratory at the Texas Army National Guard (TXARNG) property known as Fort Jacob F. Wolters, located near Mineral Wells, Texas.

\subsection{Authority for the Preliminary Assessment}

The National Guard Bureau, Army Directorate, has engaged Argonne to perform PAs of selected National Guard properties. These assessments are being done in a manner consistent with both the Department of Defense Installation Restoration Program (IRP) and the U.S. Environmental Protection Agency's (EPA's) Potential Hazardous Waste Site Preliminary Assessment Guidance. Preliminary assessinents of National Guard properties are conducted under the authority and direction of the IRP; the Comprehensive Environmental Response, Compensation, and Liability Act (CERCLA or, more commonly, Superfund); and the Superfund Amendments and Reauthorization Act of 1986 (Public Law 99-499).

\subsection{Objectives}

This PA report is based on existing information from the National Guard records that were made available to Argonne investigators and from other sources. Although this PA effort did not extend to the generation of new data, it nonetheless identifies areas where existing data are incomplete, unreliable, or ambiguous and recommends ways to address such shortcomings.

The objectives of the PA are to satisfy Phase I of the IRP and to

- Identify and characterize the environmentally significant operations (ESOs),

- Identify property areas or ESOs that may require a site investigation,

- Identify ESOs or areas of environmental contamination that may require immediate removal,

- Identify properties for which no further action is needed, and 
Provide information sufficient to prescore the site with the EPA's PA Scoresheets (September 1991).

\subsection{Procedures}

The PA began with a review of files located at TXARNG Headquarters at Camp Mabry in Austin, Texas, on May 24, 1993. Other relevant information was obtained on May 25 from the Texas Water Commission, the U.S. Department of Agriculture Soil Conservation Service, and other state and federal agencies. A site visit was conducted on May 27 to obtain additional information through direct observation and interviews with personnel familiar with the property and its operations (Dennis 1993).

\subsection{Report Format}

This PA report presents a summary and evaluation of the data relevant to the PA for this property. Section 2 describes the property and its surrounding environment and land uses. Section 3 identifies and characterizes the ESOs at the site. Section 4 discusses known and suspected releases to the environment, and Section 5 discusses potential human and environmental receptors for such releases. Section 6 summarizes the findings and conclusions, discusses the quality and reliability of the supporting information, identifies areas requiring further action, and (as appropriate) suggests how such actions can be accomplished. Section 7 lists pertinent materials reviewed. The Appendix provides interview information. 


\section{Property Characterization}

\subsection{General Property Information}

Fort Wolters is 3 mi east of Mineral Wells, Texas, which is in Palo Pinto County. Fort Wolters is a large TXARNG training facility presently comprising 3,985 acres, the majority of which extends northeast into Parker County. Weatherford, Texas, located in Parker County, is approximately $15 \mathrm{mi}$ east of the property, and Fort Worth, Texas, is approximately $15 \mathrm{mi}$ farther east. Major access routes are State Highway 180 and State Highway 281. Figure 1 shows the general location of the Fort Wolters property, and Table 1 lists pertinent information about it.

The federally owned Fort Wolters property has a long history of military activity dating from 1925 (Hall 1988). During World War II and for some years after, land used by the federal government for military training was approximately twice that now available and included a substantial cantonment area. A significant portion of the former, more extensive Fort Wolters property, essentially all of the former cantonment area, has since been redeveloped by Mineral Wells as commercial, industrial, and residential areas. Much of the central portion of the former Fort Wolters property was transferred to state and local agencies for use as parks and forest preserves. Most of the property now licensed to the TXARNG remains undeveloped and is used for firing range and training activities. Included in the facility are the former Nike-Hercules Missile Defense Program missile launch area (MLA) and integrated fire control (IFC) area designated DF-70.

\subsection{Description of Facilities}

The Fort Wolters property is licensed to the TXARNG as a range and training site. Since acquisition, Fort Wolters has been used extensively for all types of training. It is the primary training, area for two tank battalions, an armored cavalry squadron, a forward support battalion, and many smaller units of the TXARNG (Whisenhunt 1987). The property is used extensively for aerial drop training by the Texas Air National Guard and the active U.S. Air Force. Fort Wolters is also used by the Army Reserve, the Marine Corps Reserve, the Reserve Officer Training Corps, and the Texas State Rifle Association when these activities do not interfere with military training. Figure 2 shows the general locations of training areas and activities. 


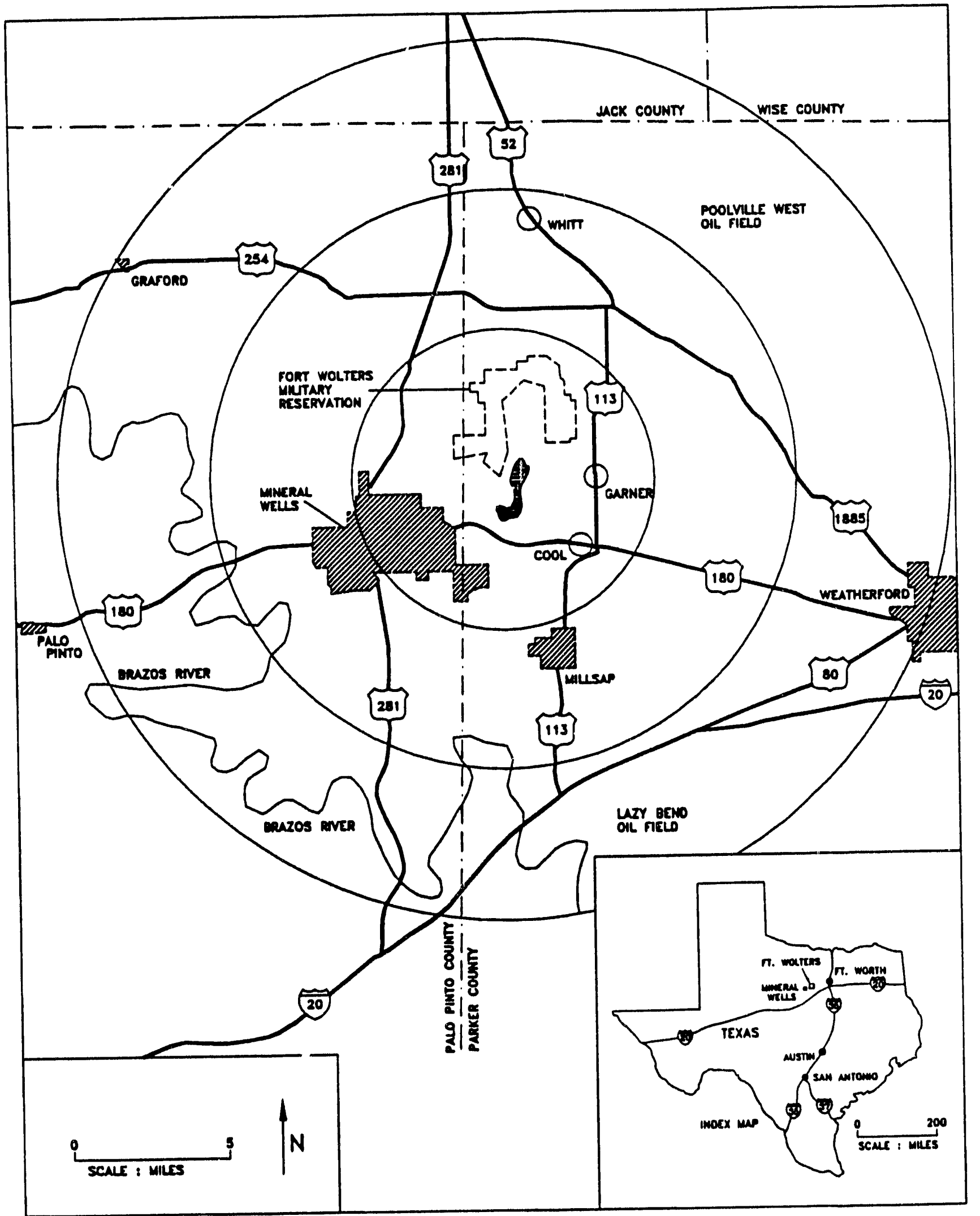

FIGURE 1 General Location of Fort Wolters (Sources: Adapted from USGS 1959a, 1959b) 
TABLE 1 Identifying Information for Fort Wolters

\begin{tabular}{|c|c|}
\hline Installation address & $\begin{array}{l}\text { Fort Wolters Training Facility } \\
\text { Rt. } 4 \text {, Building } 1202 \\
\text { Mineral Wells, TX } 76067\end{array}$ \\
\hline \multicolumn{2}{|l|}{ Geographic location } \\
\hline Latitude & $32^{\circ} 50^{\prime} \mathrm{N}$ \\
\hline Longitude & $98^{\circ} 03^{\prime} \mathrm{W}$ \\
\hline FISPa installation number & 48555 \\
\hline Commander & Maj. Gary L. Huffman \\
\hline Type of facilities & $\begin{array}{l}\text { Unit Training Equipment Site } \\
\text { Firing range } \\
\text { Aerial drop zone } \\
\text { Training site } \\
\text { Former Nike missile launch area and fire control facility }\end{array}$ \\
\hline License information & Federally owned, licensed to the state of Texas \\
\hline Principal contact & $\begin{array}{l}\text { James F. Resner } \\
\text { (512) } 465-5629\end{array}$ \\
\hline
\end{tabular}

a Facility Inventory and Stationing Plan.

Source: NGB (1988).

\subsubsection{Unit Training Equipment Site 2}

The Unit Training Equipment Site 2 (UTES 2) is in the southern portion of the TXARNG property, at the intersection of Wagner Road and Heintzelman Road (FHHH 1988). The UTES 2 provides facilities for maintenance of the approximately 35 wheeled and 65 tracked vehicles assigned to the unit. Operations performed include general vehicle maintenance, vehicle fueling, and vehicle and equipment washing. Vehicle maintenance activities include fluid changes (i.e., oil, transmission fluid, and antifreeze/coolant), filter changes (i.e., gas, oil, air, transmission filters), brake repair, lubrication of axles and drive trains, battery changes, tire repair and replacement, engine repair, transmission repair, electronic repair, minor welding and body repair, and minor spot painting. A diagram of the UTES 2 and supporting facilities is provided as Figure 3. 


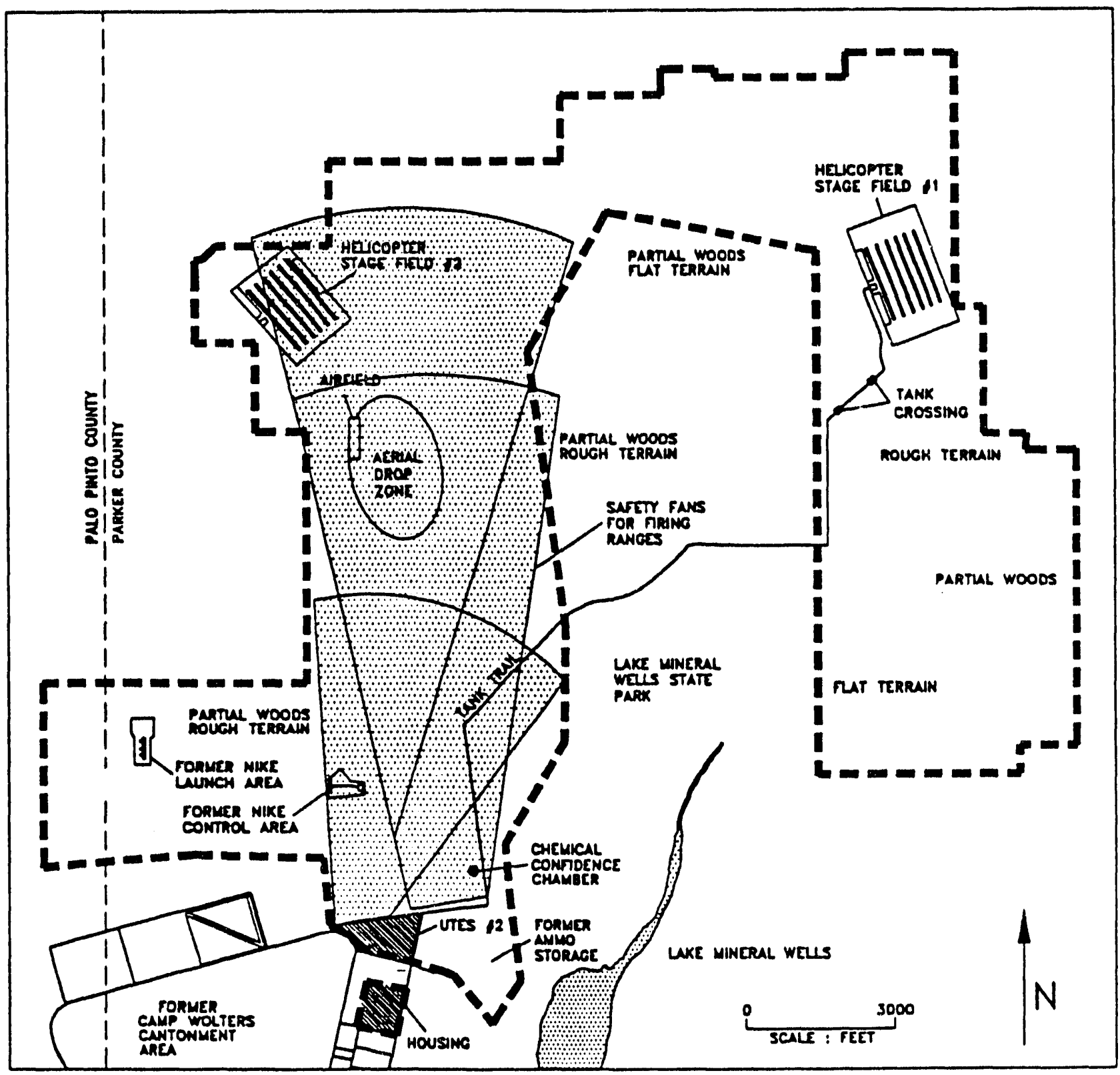

FIGURE 2 Location of Fort Wolters Training Areas and Activities (Source: Adapted from Hall 1988) 


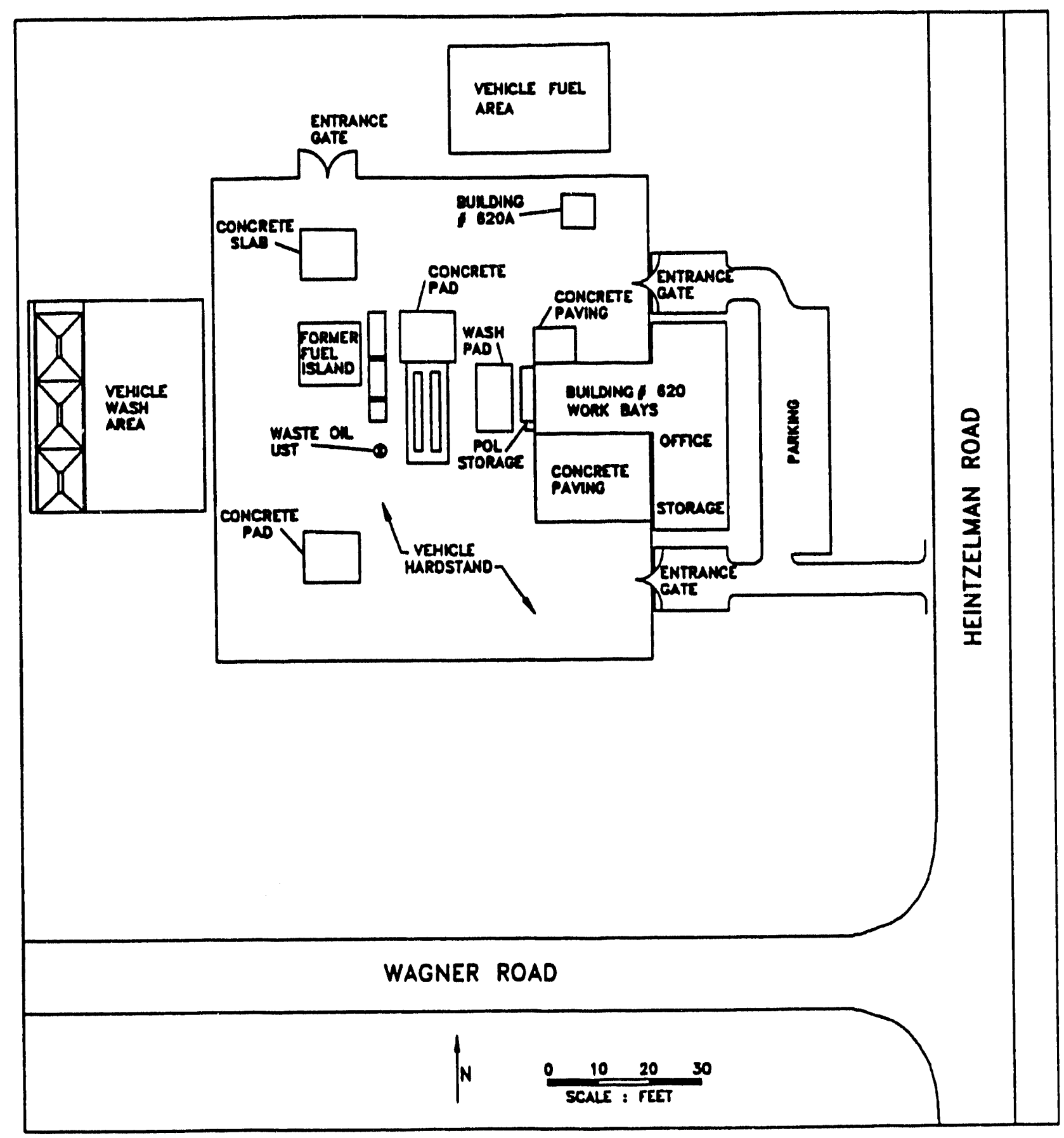

FIGURE 3 Fort Wolters Unit Training Equipment Site 2 (Source: Adapted from FHHH 1988) 
Building 620 (the main shop) is a single-story structure set on a concrete slab foundation with concrete slab walls and a vulcanized rubber roof covered with gravel (USACE 1993). The $8,180-\mathrm{ft}^{2}$ building was constructed in 1989. Its eastern portion consists of offices, supply and storage rooms, latrines, a communications room, and a break room. The inner walls are primarily drywall. Most floors and ceilings are tile covered. The western portion of the building consists of a large open bay with three maintenance work areas. The walls and ceiling are metal, and the floor is exposed concrete. Drains within the shop area lead to an oil-water separator. Attached to the work bay is a storage shed for petroleum, oils, and lubricants (POL). The 100- $\mathrm{ft}^{2} \mathrm{POL}$ storage area is an all-metal room on a concrete slab foundation. Access to the POL storage shed is from outside Building 620.

Building $620 \mathrm{~A}$, to the north of Building 620 , is the hazardous waste storage building. It was constructed in 1989 . The $436-\mathrm{ft}^{2}$ building is of metal construction on a ccrcrete slab foundation. Building 615 , built in 1985 , serves as a battery storage building. Th: $144-\mathrm{ft}^{2}$ building is a single-story, all-cement structure. Neither building has floor drains. Surbing is present within the hazardous waste storage building to prevent movement of haza:dous fluids outside the building in the event of a spill. The battery storage building is partially cu:bed; curbing is not present at the doorway.

A vehicle wash area is located west of the Building 620 POL storage shed. Drainage from the wash area is directed through the oil-water separator before it is discharged into the sanitary sewer system. Waste oil from the oil-water separator is stored in a 1,000-gal underground storage tank (UST) (TXARNG 1992b). A lubrication rack is available for vehicle inspections. A fueldispensing area with a 6,000-gal UST for gasoline and an 8,000-gal UST for diesel fuel is no longer used, and the USTs have been removed.

Outside the fenced area of the UTES 2 are vehicle washing and refueling areas for use by TXARNG personnel during weekend or annual training exercises. The vehicle wash area is approximately $180 \mathrm{ft}$ west of Building 620 (FHHH 1988). Three vehicle wash bays drain through sedimentation tanks to an oil-water separator. Wash water is recycled. Diesel fuel is stored in a 14,000-gal aboveground storage tank located north of Building 620A (BWR 1990). The tank is located within a concrete retaining basin sloped to a sump drain. A leak detection jacket encloses the joint of the connecting piping from the storage tank. Dispensing equipment is located on a concrete fueling pad. The diesel fuel storage and dispensing system was installed in 1991. 


\subsubsection{Exercise Area Maintenance Facility (Former Nike Missile Base)}

The exercise area maintenance facility is located in the northern portion of the TXARNG property. This facility serves as a motor park, a maintenance facility, and a command post for Fort Wolters' exercise areas (Whisenhunt 1987). Operations performed include general vehicle maintenance, vehicle fueling, and vehicle and equipment washing. This facility was constructed in 1959-1960 as a Nike missile launch area (MLA) (USACE 1958). The Nike integrated fire control (IFC) area was approximately 3,000 ft east of the MLA. When the TXARNG received license to the Fort Wolters property in 1974, the former MLA was redeveloped as a UTES, and some structural modification and additions were made (Adams 1976). A diagram of the exercise area maintenance facility is provided as Figure 4.

Building 1201 serves as a guardhouse. The one-room building is a single-story structure, $39 \mathrm{ft}^{2}$ in area, set on a concrete slab foundation with cinder block walls and an asphalt-gravel roof. The inner ceiling is drywall, and the floor is exposed concrete (USACE 1993).

Building 1202 serves as the facility manager's office. The 1,785- $\mathrm{ft}^{2}$ building, consisting of office space, an operations break room, a latrine, and utility rooms, is a single-story structure set on a concrete slab foundation with cinder block walls and a flat tar-gravel roof. The walls are cinder block, the ceilings are drywall, and the floor is primarily carpet glued over floor tile.

Building 1205 serves as a warehouse for nonhazardous materials. The building is a singlestory structure, $1,925 \mathrm{ft}^{2}$ in area, set on a concrete slab foundation with cinder block walls and a flat tar-gravel roof. Inner walls of the warehouse are cinder block, and the floor and ceiling are concrete.

Building 1206, the state maintenance shop, consists of an office, a work bay, a latrine, and a mechanical room. The 1,573- $\mathrm{ft}^{2}$ building is a one-story structure set on a concrete slab foundation with cinder block walls and a gently sloping tar-gravel roof. The floor in the office is tile covered; the ceiling is drywall. The floor in the large work bay is exposed concrete; the ceiling is metal. When it was constructed in 1960 for the Nike missile facility, the building served as the missile assembly and test building. In 1976, the TXARNG modified Building 1206 to facilitate vehicle maintenance operations (Adams 1976). The work bay area was expanded. The battery room was improved by the addition of a new door, a door frar :, and a concrete slab floor that sloped to a floor drain. An acid-resistant sink and splash plates were added, as was an emergency 


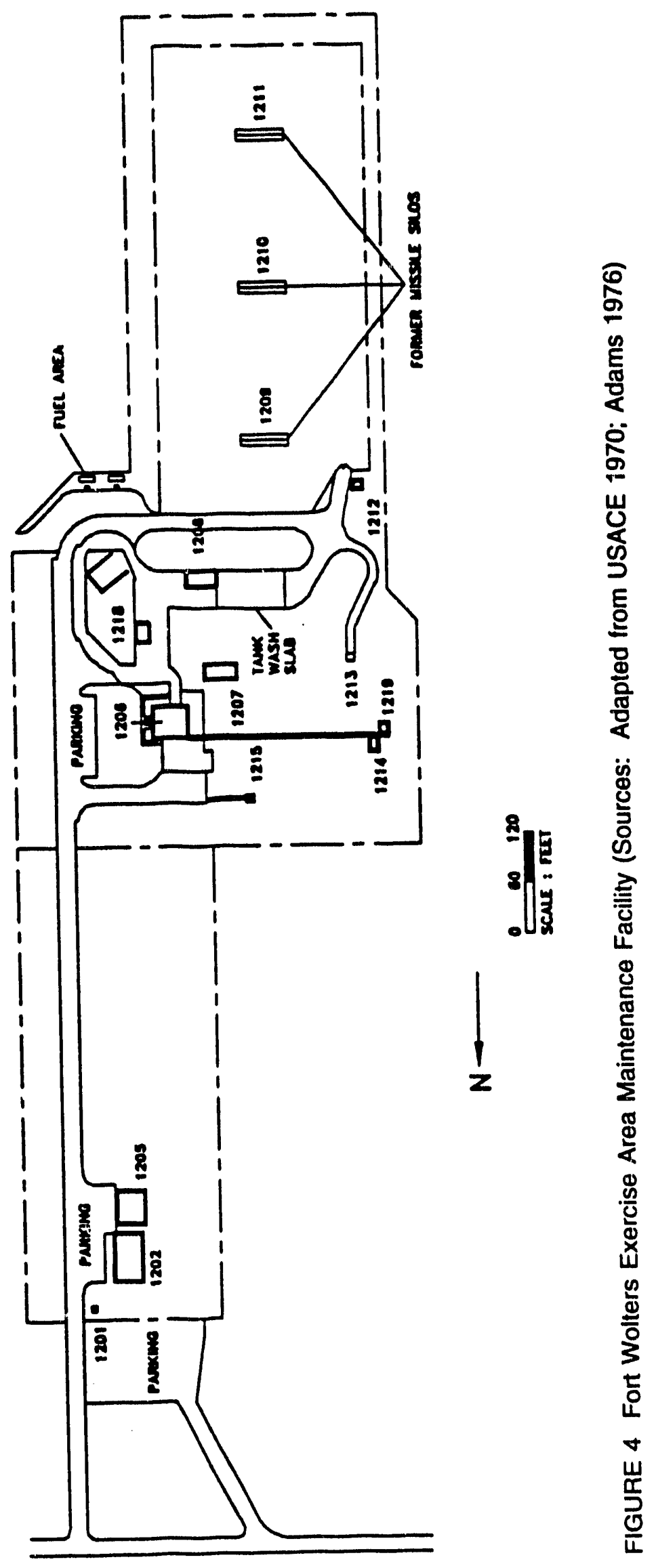


shower decontamination unit. Two 5,000-gal USTs and associated fuel-dispensing equipment were installed for diesel fuel and gasoline. A portion of an existing dirt berm, built to provide a measure of protection for former Nike workers, was removed to facilitate traffic flow. In 1988, two USTs (a 6,000-gal UST for diesel fuel and a 4,000-gal UST for gasoline), which dated from the former Nike operations and which were no longer used, were removed.

Building 1207 serves as a warehouse. The $829-\mathrm{ft}^{2}$ building is a single-story, one-room structure set on a concrete slab foundation with cinder block walls and a flat tar-gravel roof. The floor is exposed concrete; the ceiling is drywall. When it was constructed in 1960, Building 1207 housed a diesel-fueled emergency power generator.

Building 1208 is a welding shop. The $787-\mathrm{ft}^{2}$ building is a single-story structure set on a concrete slab foundation with cinder block walls and a flat tar-gravel roof. The floor is exposed concrete; the ceiling is metal. Adjacent to Building 1208 is a tank washrack that is not currently used. No oil-water separator is available to filter drainage from the tank wash slab.

Buildings 1209, 1210, and 1211 were constructed in 1960 as missile silos and are currently abandoned. Each $5,788-\mathrm{ft}^{2}$ building is an underground structure with a concrete slab foundation and concrete walls. Roofs are cement slab mounds on the ground surface.

Building 1212 is not used. The $96-\mathrm{ft}^{2}$ structure is set on a concrete slab foundation and has an all-wood frame and walls and an asphalt shingle roof. Building 1212 was a sentry control station when it was part of the former Nike operations.

Building 1213 is a storage shed for nonhazardous equipment and materials. The $42-\mathrm{ft}^{2}$ building is all metal on a cement slab foundation, with no interior finish. During the former Nike operations the building served for acid storage.

Building 1215 is used for POL storage. The $51-\mathrm{ft}^{2}$ single-story structure is set on a concrete slab foundation with cinder block walls and an asphalt-gravel roof. During the former Nike operations, Building 1215 was used for storage of paint and oil.

Building 1219 was built in 1965 and serves as a storage shed for flammable materials. The $144-\mathrm{ft}^{2}$ building is all metal on a cement slab foundation, with no interior finish. 
Portions of the former Nike IFC area have been used by TXARNG units, primarily for storage of nonhazardous equipment, during training periods. Building 1178 was built in 1959 and serves as a guardhouse. The $64-\mathrm{ft}^{2}$ building is a single-story structure set on a concrete slab foundation, with cinder block walls and an asphalt-gravel roof. The 1,131- $\mathrm{ft}^{2}$ Building 1179 is no longer used, but it did serve as a recreation hall. It is a single-story structure set on a concrete slab foundation with cinder block walls and a flat tar-gravel roof. The floor is tile covered; the ceiling and walls are drywall. Building 1180 serves as a generator building. It is a single-story structure, $964 \mathrm{ft}^{2}$ in area, set on a concrete slab foundation with cinder block walls and an asphalt roof. Floors are primarily exposed cement. Walls are cinder block; the ceiling is drywall. Building 1188 was constructed in 1964 and serves as a warehouse. The 1,018- $\mathrm{ft}^{2}$ building is a single-story metal structure set on a concrete slab foundation. Floors are either exposed cement or tile covered. Walls are primarily Transite board; ceilings are tile. Two USTs (a 6,000-gal UST for diesel fuel and a 4,000-gal UST for gasoline) dating from the former Nike operations were removed in 1988, when they were no longer used.

\subsubsection{Training Areas}

Over 3,900 acres of land are available for field training by armor, armored cavalry, infantry, artillery, engineers, medical, aviation, and other troop units (Hall 1988). Light-duty and unimproved roads provide access throughout the training site for tank and troop maneuver operations. Helicopter stage fields in the northern portion of the training area, built in 1957, are used as field billeting and rendezvous areas. Wells at the two locations supply water resources.

Buildings 1101 and 1102 are located at Stage Area 1 (Grid 928380, as identified by Hall [1988]). The $990-\mathrm{ft}^{2}$ Building 1101 range house is not currently used. It is a three-room, singlestory structure set on a concrete slab foundation with an asphalt shingle roof and Transite siding walls. The floor is either exposed cement or tile covered; interior walls and ceiling are drywall. Building 1102 serves as a water pump house. The $48-\mathrm{ft}^{2}$ single-story building is set on a concrete slab foundation with wood fiame construction, Transite siding on the exterior walls, and an asphalt shingle roof. Interior walls are drywall; the floor is cement (USACE 1993). The well at this location was drilled to a depth of $400 \mathrm{ft}$ (TDH 1986).

Buildings 1121 and 1122 are located at Stage Area 2 (Grid 889377). The 1,269- $\mathrm{ft}^{2}$ Building 1121 range house is not currently used. It is a three-room, single-story structure set on a concrete slab foundation with an aspnalt shingle roof and Transite siding walls. The floor is either 
exposed cement or tile covered. Interior walls are drywall; ceilings are bare. Building !122 serves as a water pump house. The $36-\mathrm{ft}^{2}$ single-story building is set on a concrete slab foundation with wood frame construction, wood siding on the exterior walls, and an asphalt shingle roof. Interior walls are wood; the floor is cement. The well at this location was drilled to a depth of $360 \mathrm{ft}$ (TDH 1986).

Building 630, at the southern end of the training area, serves as a field kitchen and administration headquarters. The $1,883-\mathrm{ft}^{2}$ building is a single-story structure set on a concrete slab foundation with metal siding and an asphalt slingle roof. The building, constructed in 1941, consists of two dining areas, a kitchen, a bunk room, and a supply room.

The former ammunition storage sacility for the old Fort Wolters operations, located east of the UTES 2, is used as a helicopter staging area and as a storage facility for bulky items that TXARNG units can preposition before training exercises (Whisenhunt 1987). Support buildings in the area include Building 622, constructed in 1957; Building 615, constructed in 1985; Buildings 601, 602, and 602A, constructed in 1987; and Building 604, constructed in 1988. Building 622 is a $65-\mathrm{ft}^{2}$ guardhouse, set on concrete slab foundation with cinder block walls and a cement slab roof. Building 601 is a maintenance shed. It is a single-story structure, $2,340 \mathrm{ft}^{2}$ in area, set on a concrete slab foundation with wood frame construction and a metal roof and siding. Building 602 also serves as a maintenance shed. It is a single-story structure, $3,200 \mathrm{ft}^{2}$ in area, built on a foundation partially of concrete slab and partially of dirt, with wood frame construction and a metal roof and siding. Building $602 \mathrm{~A}$ is $3,075-\mathrm{ft}^{2}$ shelter for vehicles and personnel. It is a pole structure built on a foundation partially of concrete slab and partially of dirt, with a steel roof and no walls. Building 604 serves as a maintenance office for visiting TXARNG personnel. The 224- $\mathrm{ft}^{2}$ building is a single-story structure set on a concrete slab foundation with metal siding and roof. It has a cement floor; the inner walls and ceiling are drywall (USACE 1993).

Specialized field training areas include tank courses and a chemical confidence chamber. Building 658 , constructed in 1969 , is the gas mask training facility. The $600-\mathrm{ft}^{2}$ building is a single-story structure set on a dirt floor with two concrete slabs. The sides and roof of the building are all metal.

Aviation facilities at Fort Wolters include an approximately 370-acre aerial drop zone for use by the 136th Tactical Airlift Wing and the 181 st Tactical Airlift Squadron stationed at Hensley Field, Dallas, Texas (NGB 1978). Operations include aerial drops of paratroops and palletized 
equipment and supplies. Aircraft landing facilities are available at the Forward Tactical Landing Strip and the two helicopter stage fields located in the northern training area.

\subsubsection{Firing Ranges}

Firing ranges at Fort Wolters provide for both individual and crew weapons training (Hall 1988). The types of firing ranges and firing positions available at the site are listed in Table 2. Ammunition stored at the site is listed in Table 3. A co-use agreement is in effect with the Texas State Rifle Association for use of the known-distance rifle range, which was constructed and is maintained by the Texas State Rifle Association (Cain 1986). Support facilities at the firing ranges include an observation tower, an ammunition issue building, target storage sheds, and a latrine. Because of the horseshoe shape of Fort Wolters, access to maneuver areas is through the safety fans of the firing ranges.

\subsubsection{Housing and Utilities}

On the basis of troop usage data, the NGB determined that the size of Fort Wolters for training purposes is 500 (one battalion size unit [NGB 1986]). Approximately 20 full-time employees are at Fort Wolters. Housing and dining facilities for approximately 500 persons, constructed in 1965, are available in the cantonment area south of the UTES 2. Building 738

TABLE 2 Firing Ranges at Fort Wolters

\begin{tabular}{lc}
\multicolumn{1}{c}{ Type } & Total Firing Points \\
\hline Pistol & 10 \\
Rifle & 25 \\
Shotgun & 5 \\
M203 grenade launcher & 12 \\
Submachine gun & 10 \\
M60 machine gun & 5 \\
Tank Table I and II & 0 \\
Tank Table III & 5 \\
Tark Table IV & 5 \\
Tank Table V & 1 \\
\end{tabular}

Source: Hall (1988). 
TABLE 3 Ammunition Stored at Fort Wolters

\begin{tabular}{lrr}
\hline \multicolumn{1}{c}{ Type } & $\begin{array}{r}\text { Rounds } \\
\text { Stored }\end{array}$ & $\begin{array}{c}\text { Number Consumed } \\
\text { Monthiy }\end{array}$ \\
\hline 5.56 millimeter & 24,754 & 6,780 \\
0.22 caliber & 23,750 & 25 \\
7.62 millimeter & 6,300 & 800 \\
Chemical agent capsules & 3 & 10 \\
\hline
\end{tabular}

Source: TXARNG (1991).

serves as women's barracks and administration building. The 4,900- $\mathrm{ft}^{2}$ building is a single-story structure set on a concrete slab foundation with cinder block walls and an asphalt shingle roof. Floors are primarily tile covered, and walls and ceiling are primarily drywall. Building $741 \mathrm{~N}$ and Building 741S serve as men's barracks. Each building is a two-story structure set on a concrete slab foundation with cinder block walls and an asphalt shingle roof. The buildings, designated as 741 north and 741 south, are connected by a two-story shower-latrine facility. The combined area of Building $741 \mathrm{~N}$ and Building $741 \mathrm{~S}$ is $10,950 \mathrm{ft}^{2}$. Dining facilities are provided in Building 742 . This $9,850-\mathrm{ft}^{2}$ building is a single-story structure set on a concrete slab foundation with cinder block walls and a metal roof. The floor is exposed cement; ceiling materials include drywall, fiberglass tile, and Transite (USACE 1993).

Fort Wolters has no medical facility. A civilian hospital (Palo Pinto General Hospital) is located $8.1 \mathrm{mi}$ west of the facility in Mineral Wells. A military hospital at Carswell Air Force Base is located approximately 38 mi east of the facility, in Fort Worth (Hall 1988).

Water and sanitary sewer service for the facility are supplied by the Mineral Wells municipal utilities. Natural gas lines are installed to the exercise area maintenance facility (the former Nike MLA and IFC area). Butane gas tanks are located on the south side of Building 1207 and the north side of Building 1181 . Electrical service to areas of the property is provided via overhead and underground distribution lines (Hall 1988). 


\subsection{Property History}

The Fort Wolters property was originally developed in 1925 when Brigadier General Jacob F. Wolters, commander of the 56th Cavalry Brigade, received a grant to construct a training camp for his TXARNG soldiers. Fifty acres were donated by the city of Mineral Wells, and an additional 2,300 acres were leased for maneuvers three weeks of each year.

In October 1940, Mineral Wells was selected as the location for an Infantry Replacement Center of sufficient capacity to house 17,000 soldiers. By securing individual leases from owners of private lands adjacent to Fort Wolters, the city assembled a tract of 7,500 acres that was then leased to the War Department. On March 22, 1941, construction of Camp Wolters was completed, and the camp was officially turned over to the U.S. Army. After World War II, the camp became the site of a helicopter training center and was also used as a Nike-Hercules MLA and IFC area.

The helicopter training grew with the Vietnam Conflict. In 1963, the facility was designated a permanent installation and renamed Fort Wolters. The training facilities for helicopter pilots were upgraded and expanded. Local farmers and ranchers donated land off-post for the construction of numerous heliports or staging fields, and in 1969 the facility was considered the world's largest primary helicopter training base. The reservation eventually comprised over 7,800 acres (USACE 1970). As the Vietnam Conflict was resolved, training was reduced.

In 1975, approximately 3,000 acres of land and 67 buildings, including essentially all of the former cantonment area, were conveyed to cities and schools in Palo Pinto and Parker counties and to the state of Texas (Starr 1975). The southern portion of the reservation has been developed by Mineral Wells as commercial-industrial and residential areas. The central portion of the property is a recreational state park that includes Lake Mineral Wells. The remaining 3,985 acres continue under federal ownership and since August 8, 1974, have been licensed (License DACA63-3-75-0023) to the TXARNG for military training (Cottrell 1979).

\subsection{Permitting Status}

The Fort Wolters installation has no ESOs requiring permits under the Resource Conservation and Recovery Act (RCRA) and none designated for CERCLA activities. Because of its solid waste management activities, the UTES 2 is registered with the Texas Department of Health as a small-quantity waste generator, identification number 55132 (Bennett 1985). 
According to the requirements of the Underground Storage Tank Program, site USTs have been registered with the Texas Water Commission (TWC 1986).

\subsection{Surrounding Environment and Land Use}

\subsubsection{Demographics and Land Use}

Fort Wolters is located in a predominantly rural area, with forest and agricultural lands covering the majority of both Parker and Palo Pinto counties. Ranching and farming are the major land uses. Livestock production includes beef cattle, dairy cattle, and poultry. Commercial farm crops include oats, grain sorghum, watermelons, peaches, pears, pecans, cotton, and alfalfa. Minerals mined in the region include crude oil, natural gas, stone, and clays. The Poolville West Oil Field is approximately $12 \mathrm{mi}$ northeast of the TXARNG property (Figure 1); the Lazy Bend Oil Field is approximately 15 mi southeast (DOT 1982).

The TXARNG property is located between two population centers (Figure 1). Mineral Wells, approximately 3 mi southwest of the site in Palo Pinto County, has a population of 14,870. Weatherford, approximately 15 mi southeast of the site in Parker County, has a population of 14,804 (Rand McNally 1992). The small communities of Cool (about 4 mi south of the site), Millsap (about $6 \mathrm{mi}$ south of the site), Garner (about $4 \mathrm{mi}$ southeast of the site), and Whitt (about $5 \mathrm{mi}$ north of the site's northern boundary) have an estimated combined population of 2,000 . Many residents commute east to work in the Fort Worth metropolitan area, about 40 mi east of the TXARNG property.

The cantonment area of the former, more extensive Camp Wolters, located south of the existing TXARNG cantonment area, was substantial (USACE 1970). Since the transfer of this property to local and state agencies in 1975, it has undergone redevelopment. The former main heliport and camp maintenance areas have been developed as private commercial and light industrial properties. Weatherford College opened a west campus on a portion of the property. Much of the central portion of the former cantonment area has been designated by Mineral Wells as a city park. The troop housing facilities have been redeveloped as private and public residences. The central portion of the former camp, including Lake Mineral Wells, was designated as a state park. Figure 5 identifies the existing Fort Wolters boundary and adjacent properties. 


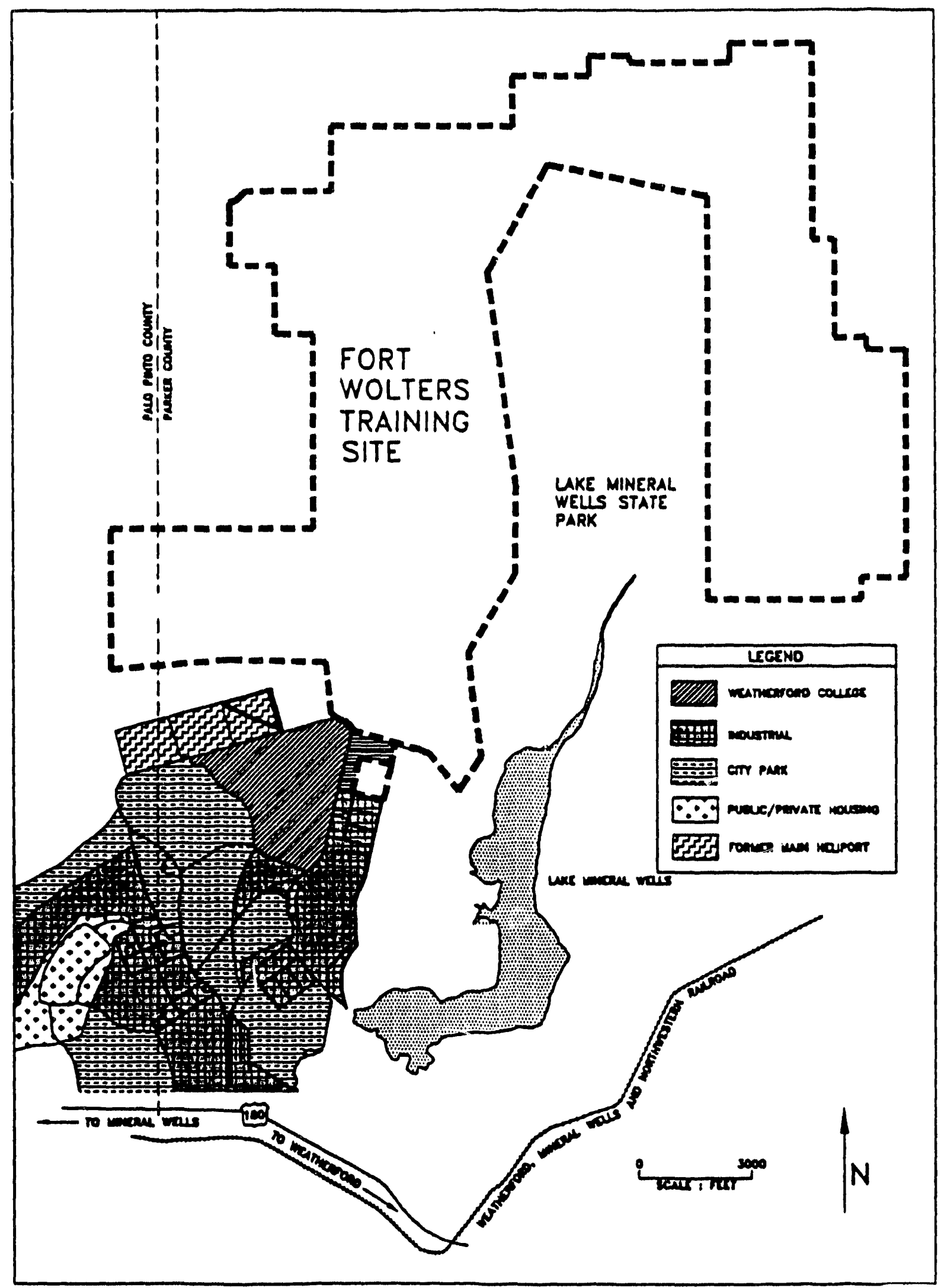

FIGURE 5 Vicinity of Fort Wolters (Source: Adapted from USACE 1978) 


\subsubsection{Climat}

The area around Fort Wolters is characterized by hot summers and dry winters. In the winter, surges of cold polar air are frequent, and cold fronts are often accompanied by strong northerly winds and sudden drops in temperature. Very cold weather rarely occurs before the end of December. Snow falls once or twice a month in January and February, but the average accumulation is less than 1 in. The average annual precipitation is about $30 \mathrm{inn}$., with the wettest months being April-May and September-October $(3.5,4,3.5$, and 3 in. average monthly precipitation, respectively). The average monthly high temperature for both July and August is about $97^{\circ} \mathrm{F}$, and the average monthly low temperatures for January and February are $31^{\circ} \mathrm{F}$ and $33^{\circ} \mathrm{F}$, respectively (Larkin and Bomar 1983). The average annual gross lake evaporation rate of $70 \mathrm{in}$. is more that twice the average annual rainfall.

During December-February, the wind blows from the north $14 \%$ of the time and from the south $18 \%$ of the time (Larkin and Bomar 1983). The wind blows from any 1 of the other 14 compass points less than $10 \%$ of the time. During March-May, the wind blows from the south fully $25 \%$ of the time and from the south-southeast $11 \%$ of the time. In June-August, the wind blows from the south $27 \%$ of the time, from the south-southwest $13 \%$ of the time, and from the south-southeast $13 \%$ of the time. In September-November, the wind blows from the south 19\% of the time, from the south-southeast $10 \%$ of the time, and from the north $11 \%$ of the time. Hence, the prevailing wind direction for the entire year is from the south, although this tendency is most pronounced in March-August.

\subsubsection{Surface Water and Physiography}

The following sections describe the local and regional surface hydrology and physiograpliy (Buckner and Shelby 1991; DHUD 1977; Dulfin and Beynon 1992; Greenwade et al. 1977; Hall 1988; Heath 1989; Nordstrom 1982; USGS 1959a, 1959b).

\subsubsection{Physiography}

Fort Wolters is located in the southeastern corner of the West Texas Rolling Prairies section of the North Central Plains physiographic province (Duffin and Beynon 1992). The Rolling Prairies section covers about $11 \%$ of the total area of the state of Texas and includes all or parts of 
44 counties in north central Texas. The topography of the Rolling Prairies generally consists of a gently sloping plain dissected by well established systems of drainage, consisting of wide valleys bounded by abrupt embankments.

Surface elevations throughout the Rolling Prairies section vary from nearly $2,600 \mathrm{ft}$ at the base of the High Plains escarpment near Palo Duro Canyon in the northwest to about $700 \mathrm{ft}$ along the main river valleys near Mineral Wells in the east. Drainage is primarily toward the east and southeast, along the general slope of the land surface.

Within Fort Wolters the terrain consists of gently rolling hills, with steep grades generated by erosion in areas of streams. The site elevation ranges from 860 to $1,039 \mathrm{ft}$ above inean sea level (Hall 1988).

\subsubsection{Soils}

Fort Wolters is situated on soils of the Truce-Bonti association, a neutral to slightly acid sandy loam found on the upland areas of Parker County (Greenwade et al. 1977). This association occurs in timbered and open areds on hills and ridges. Boulders and stones are common throughout much of the area. The Truce-Bonti association makes up about $6 \%$ of the county.

The gently sloping to steep Truce soils are on hills and the lower portions of side slopes. Some areas have stones and large boulders on the surface. The surface layer consists of a brown, fine, sandy loam about 8 in. thick. The next layer is reddish brown clay about 16 in. thick, and below this is about 24 in. of brown clay. The underlying material is pale olive shaley clay.

The gently sloping to sloping Bonti soils are on ridges. The surface layer consists of a light brown, fine, sandy loam about 10 in. thick. In many areas, the surface layer is stony. The next layer is a yellowish red clay about 22 in. thick. The underlying layer is a reddish yellow, strongly cemented sandstone.

Minor members of the association are the Bosque, Bunyan, Chaney, Hassee, Owens, Selden, Thurber, and Yahola soils. The Bosque, Bunyan, and Yahola soils are found on flood plains along major streams. Chaney and Selden soils are on foot slopes and plains. Hassee and Thurber soils are found on foot slopes, on broad plains, and in slightly depressed areas. Owens soils are on hillsides. 
The former Nike site is situated on Bonti and Truce soils with a slope of $1-8 \%$. These gently sloping stony soils are on uplands and generally follow the contours of hills and ridges. Slopes are complex, but they are mostly convex and are dominantly $2-8 \%$. Sandstone fragments ranging from cobbles to boulders cover about 10-30\% of the surface. Bonti soils make up about 50-70\% of the mapped area, while Truce soils make up the remaining 30-50\%. The soil is not suitable for cultivation. The hazard of water erosion is moderate. The soil is classified as moderately deep to deep and moderately slowly permeable to slowly permeable. The available water capacity is medium (Greenwade et al. 1977).

\subsubsection{Surface Hydrology}

The northern portion of the Rolling Prairies section, well to the north of Fort Wolters, is drained by the Red River and its tributaries. Portions of Parker County to the east of Fort Wolters are drained by the West Fork of the Trinity River. The area to the west of Fort Wolters is drained by the Brazos River through its two main tributaries, Salt Fork and Clear Fork. The area immediately surrounding Fort Wolters drains into Lake Mineral Wells, which discharges into the Brazos River via Rock Creek. Figure 6 identifies surface waters in the vicinity of Fort Wolters.

Areas of Fort Wolters near Rock Creek and Rippy Branch are within designated 100-year flood hazard areas (DHUD 1977). These waterways are in the training area of the property. No) flood hazard is present in areas of hazardous materials storage or use.

Currently, 25 major surface reservoirs with capacities of 5,000 acre-feet or more, including Lake Mineral Wells, contribute all or part of their respective yields to supply water needs within the Rolling Prairies section (Duffin and Beynon 1992). These reservoirs have combined capacities of more than 2.2 million acre-feet and can supply approximately 0.62 million acre-feet annually. Within the entire Rolling Prairies section, surface water sources in 1988 supplied a total of 59,447 acre-feet of water for public supply, 41,908 acre-feet for irrigation, 19,950 acre-feet for livestock, 14,799 acre-feet for power generation, 11,397 acre-feet for rural domestic use, 8,556 acre-feet for mining, and 8,341 acre-feet for manufacturing. Surface water supplies are considered adequate to meet current and projected needs through the year 2010 (Duffin and Beynon 1992). 


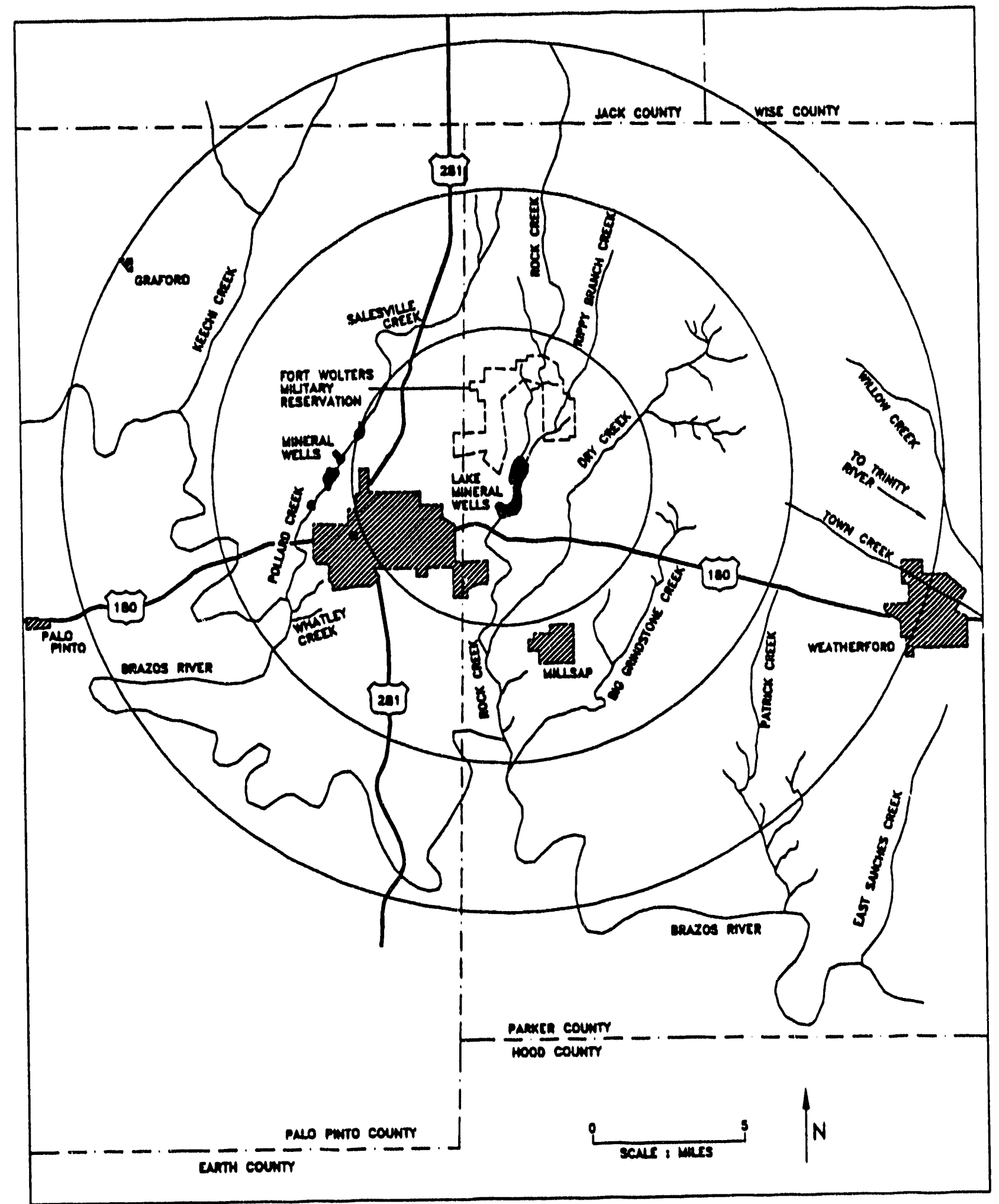

FIGURE 6 Location of Regional Surface Waters (Source: Adapted from USGS 1959a, 1959b) 
The surface water resources in the western portions of the Rolling Prairies suffer from various degrees of natural salt contamination, resulting from salt water springs and outcrops of gypsum beds. The upper reaches of the Red River and Brazos River basins are too saline for many uses. In the 1990 water year (October 1989 through September 1990), Brazos River monitoring station number 08079575 near the town of Post in Garza County, about 200 mi to the west of Fort Wolters, measured an average concentration of total dissolved solids of $2,120 \mathrm{mg} / \mathrm{L}$ (Buckner and Shelby 1991). For comparison, $500 \mathrm{mg} / \mathrm{L}$ is preferred for domestic use, and water with concentrations of total dissolved solids of $1,000-3,000 \mathrm{mg} / \mathrm{L}$ is classified as "slightly saline" by the U.S. Geological Survey (USGS) (Heath 1989). To facilitate full use of these water resources, several federally funded chloride control programs have been constructed within the Red River basin northwest of Fort Wolters (Duffin and Beynon 1992).

The surface water in the vicinity of Fort Wolters has not been as compromised by natural salt contamination. Brazos River monitoring station 08090800 near Dennis, Texas, about 15 mi southeast of Fort Wolters, recorded an average concentration of total dissolved solids of $689 \mathrm{mg} / \mathrm{L}$ for water year 1990 (Buckner and Shelby 1991).

All major cities (defined either as incorporated cities with 1980 population of 1,000 or greater or as county seats) in the vicinity of Fort Wolters depend on surface water for municipal water supplies (Duffin and Beynon 1992). In 1988, Mineral Wells obtained all of its 2,814 acrefeet of public water from surface water; none came from groundwater. The towns of Palo Pinto, Brackenridge, Bridgeport, Graham, Eastland, Ranger, Olney, and Jacksboro are all within about $50 \mathrm{mi}$ of Fort Wolters. They obtained all of the total of 6,624 acre-feet of water needed to satisfy their municipal requirements in 1988 from surface water; none came from groundwater. Only the village of Whitt in Parker County, about $5 \mathrm{mi}$ north of Fort Wolters, uses groundwater for its public water supply (Nordstrom 1982).

\subsubsection{Groundwater and Hydrogeology}

The following sections describe the local and regional geology and groundwater (Duffin and Beynon 1992; Nordstrom 1982; TWC 1993). 


\subsubsection{Regional Geology}

During most of the Paleozoic era, a sedimentary basin existed throughout much of central and north-central Texas. Sediments consisting of sandstone, limestone, carbonaceous shales, and other marine sediments were deposited in this basin until late Pennsylvanian time, when the Llano Uplift and the Ouachita Fold Belt caused a regional tilting to the west and faulting in the immediate uplift area. The Pennsylvanian-Cretaceous unconformity indicates a period of tremendous emergence and erosion. During Permian time, the basin shifted to the west, and only the Rolling Prairies region continued to receive sediments. The region to the east of Fort Wolters-Mineral Wells underwent significant erosion.

During the Triassic and Jurassic periods of the early Mesozoic era, withdrawal of the seas from north-central Texas, along with subsidence in the Gulf Coast embayment, led to a reversal of drainage direction and an extensive truncation of Pennsylvanian strata in the Fort Worth basin to the east of the Fort Wolters area. By the close of the Jurassic, Paleozoic rocks had been reduced to an almost flat, featureless plain, upon which marine sediments were deposited along an oscillating shoreline during the Cretaceous. Two major invasions of the seas during the Cretaceous are represented by the Comanche and Gulf series. During the late Cretaceous (Gulf series), a general uplift occurred to the west, and the seas withdrew gulfward.

At the close of the Cretaceous, marked by uplift in the west and subsidence along the coast, sediments of Tertiary and Quaternary age were deposited. The repeated transgression and regression of the sea resulted in an alternating sequence of marine and continental deposits. Throughout the Tertiary period, the land surface was eroded and modified by streams and rivers, except for minor periods of subsidence. During Quaternary time, the streams deposited alluvial sediments. The older sediments are represented by terrace deposits above the alluviated valleys of present streams.

\subsubsection{Local Geology}

Pennsylvanian and Permian rocks start to outcrop about $4 \mathrm{mi}$ to the east of Fort Wolters and extend to the west. Figure 7 shows the Paleozoic cross section through the Rolling Hills physiographic section (Duffin and Beynon 1992). Fort Wolters itself is situated on an outcrop of the Strawn group, of middle Pennsylvanian age. Table 4 shows the driller's log from a well 


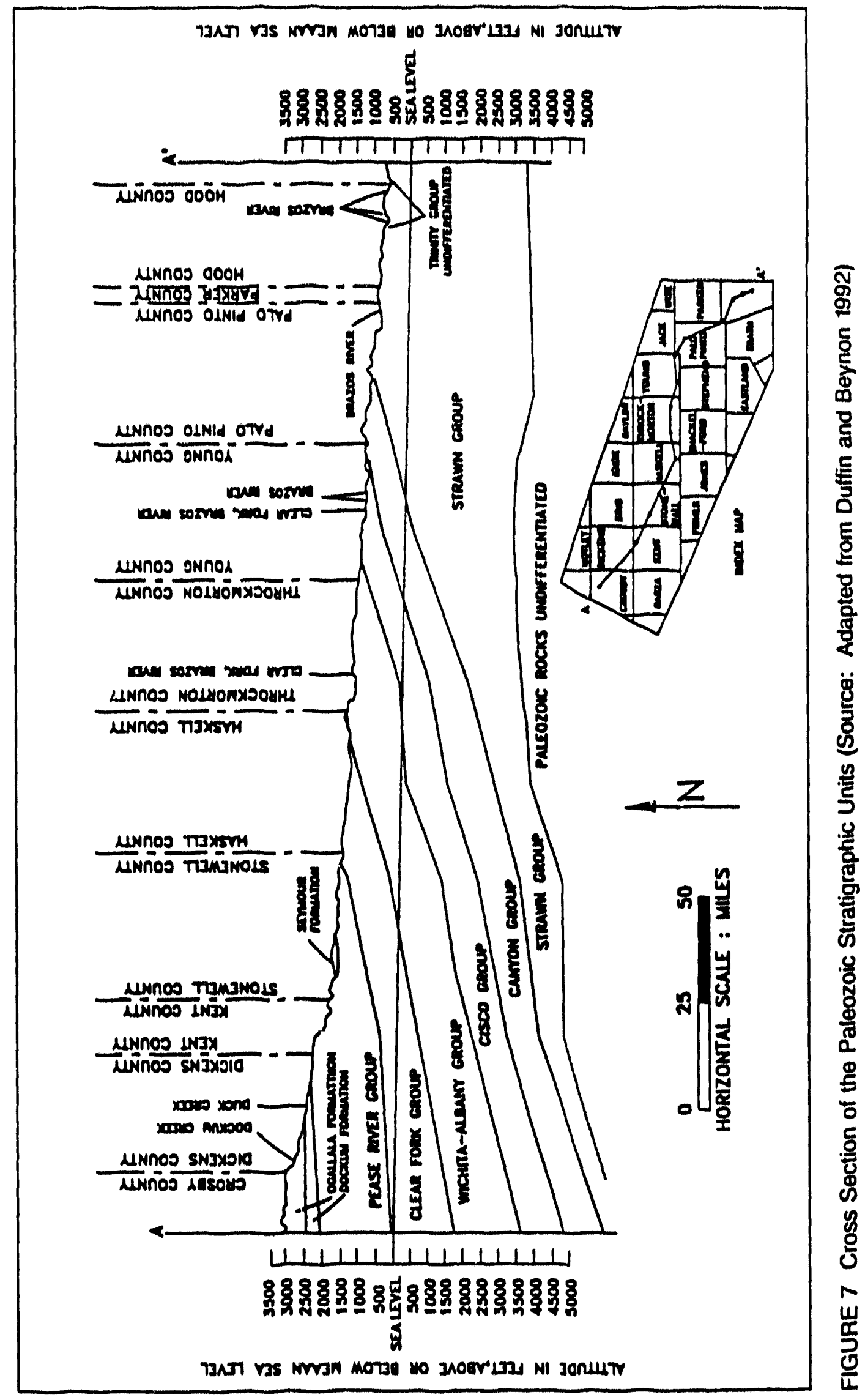


TABLE 4 Driller's Log of

Well UP.32-01.709a

\begin{tabular}{cl}
\hline $\begin{array}{c}\text { Depth } \\
(f t)\end{array}$ & $\begin{array}{c}\text { Driller's } \\
\text { Descriptlon }\end{array}$ \\
\hline 0.12 & Sandy loam \\
12.26 & Red sand \\
26.75 & Yellow clay \\
75.92 & Rock \\
92.125 & Black shale \\
125.208 & Sandstone \\
208.258 & Rock \\
258.305 & Grey shale \\
305.328 & Limestone \\
328.345 & Black shale \\
345.396 & Sandetone \\
396.400 & Limestone \\
400.430 & Black shale \\
\hline
\end{tabular}

a Well owned by Bryant's Horse Ranch and drilled by Can Drilling, July 1988.

Source: TWC (1993).

drilled within $4 \mathrm{mi}$ of Fort Wolters. (The well identification system is discussed in Section 2.5.4.4.) The Paleozoic stratigraphic units dip westward and northwestward with a slope of about $40 \mathrm{ft} / \mathrm{min}$ (Nordstrom 1982).

Cretaceous rocks start to outcrop about $4 \mathrm{mi}$ to the east of Fort Wolters and extend farther to the east. Figure 8 shows the Cretaceous cross section extending to the east of Fort Wolters (Nordstrom 1982). The Cretaceous system forms a southwestward-thickening wedge extending into the East Texas basin. Regional dip is to the east and southeast at rates of $15-40 \mathrm{ft} / \mathrm{min}$.

\subsubsection{Reglonal Groundwater}

The most important water-bearing formations in north-central Texas are of Cretaceous age. The Cretaceous system is composed of two series, the Gulf and Comanche. The Gulf series is 


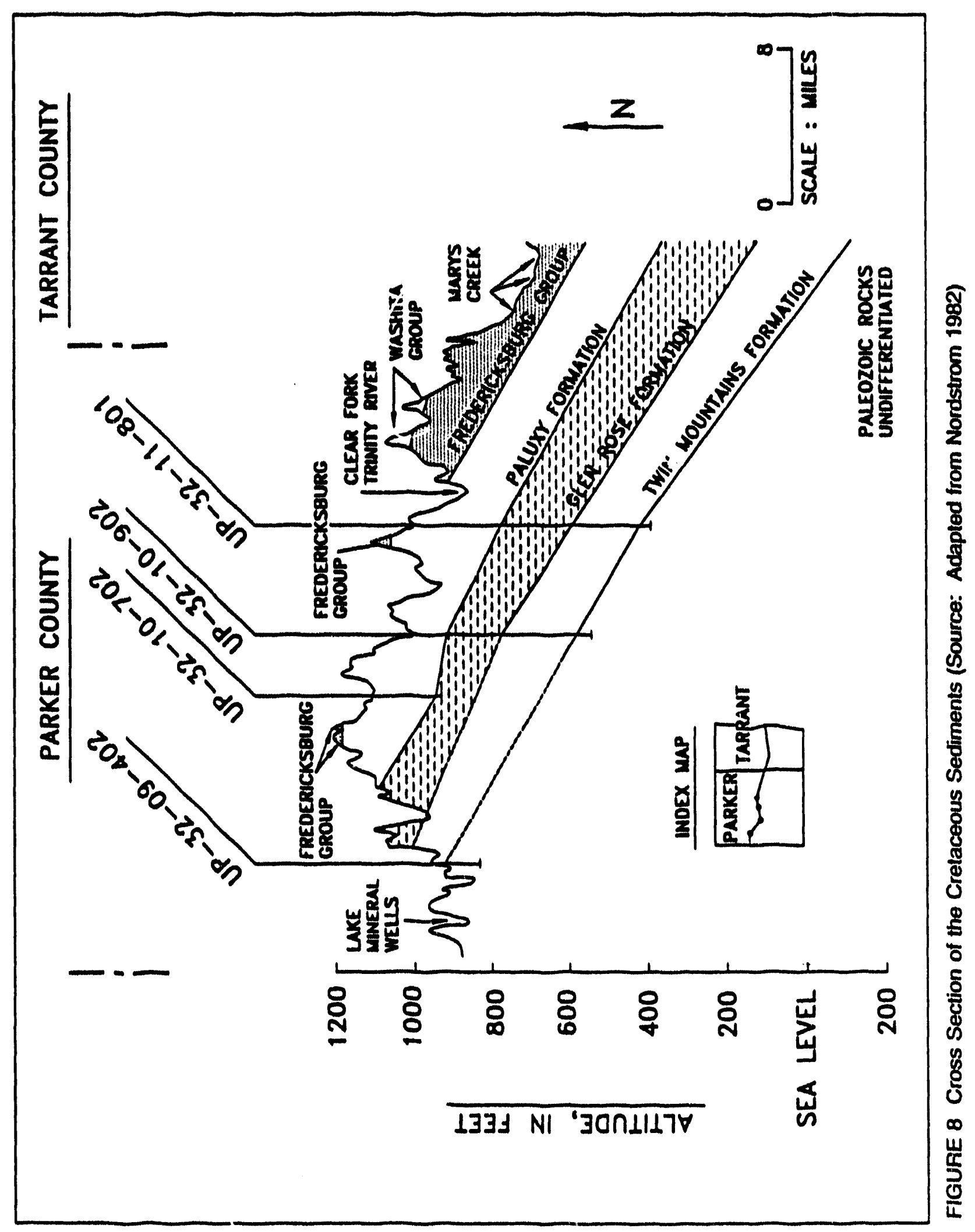


composed of the Navarro, Taylor, Austin, Eagle Ford, and Woodbine groups. The Comanche series is divided into the Washita, Fredricksburg, and Trinity groups.

The Trinity group, the principal water-bearitig group of rocks in the area, is divided into the Paluxy, Glen Rose, Twin Mountains, and Antlers formations. The Twin Mountains formation outcrops about $4 \mathrm{mi}$ to the east of Fort Wolters and is composed of conglomerate, sand, and shale. The Twin Mountains is the principal water-bearing formation of Cretaceous age in the region and yields moderate to large amounts of water. (For the purposes of this PA, a small well yield is less that $100 \mathrm{~g} \mathrm{gl} / \mathrm{min}$, a moderate well yield is $100-1,000 \mathrm{gal} / \mathrm{min}$, and a large yield is over $1,000 \mathrm{gal} / \mathrm{min}$.) Yields of wells completed in the Twin Mountains range from 10 to $1,940 \mathrm{gal} / \mathrm{min}$, with an average yield of $286 \mathrm{gal} / \mathrm{min}$ (Nordstrom 1982). Yields are considerably lower on or near the outcrop than farther downdip. The primary source of groundwater in the Twin Mountains is precipitation falling on the outcrop.

Fort Wolters itself is located on the southwestern boundary of the Southern Great Plains hydrogeologic region (Jorgensen et al. 1988). The Paleozoic outcrops in Parker and Palo Pinto counties represent the surface discharge area for the "deep-basin brine" aquifer system, as shown in Figure 9 (Jorgensen et al. 1988). The deep-basin brine aquifer system includes aquifers in Pennsylvanian and Lower Permian shelf and shelf-margin carbonates, aquifers in lower Paleozoic shallow-marine carbonates, and aquifers in upper Paleozoic arkosic or granite-wash sundstones.

The present direction of groundwater flow is generally eastward in each hydrogeologic element of the deep-basin brine aquifer system (Jorgensen et al. 1988). Discharge areas for the deep-basin brine aquifer system lie in the broad outcrop of Pennsylvanian and Lower Permian formations throughout north-central Texas and southwestern Oklahoma. Permeable fluvial-deltaic sandstone and shelf-margin carbonate banks provide narrow paths across the discharge area for fluid movement out of the Midland basin. Vertical hydrologic continuity is restricted by thin, widespread beds of carbonate mudstone and interfluvial shale deposits. The fresh groundwater system of meteoric origin circulates to only a shallow depth in the regional discharge zone.

\subsubsection{Local Groundwater}

The most important Paleozoic freshwater-bearing formations in the vicinity of Fort Wolters are the Wichita group of the Permian system and the Cisco group of the Pennsylvanian system 


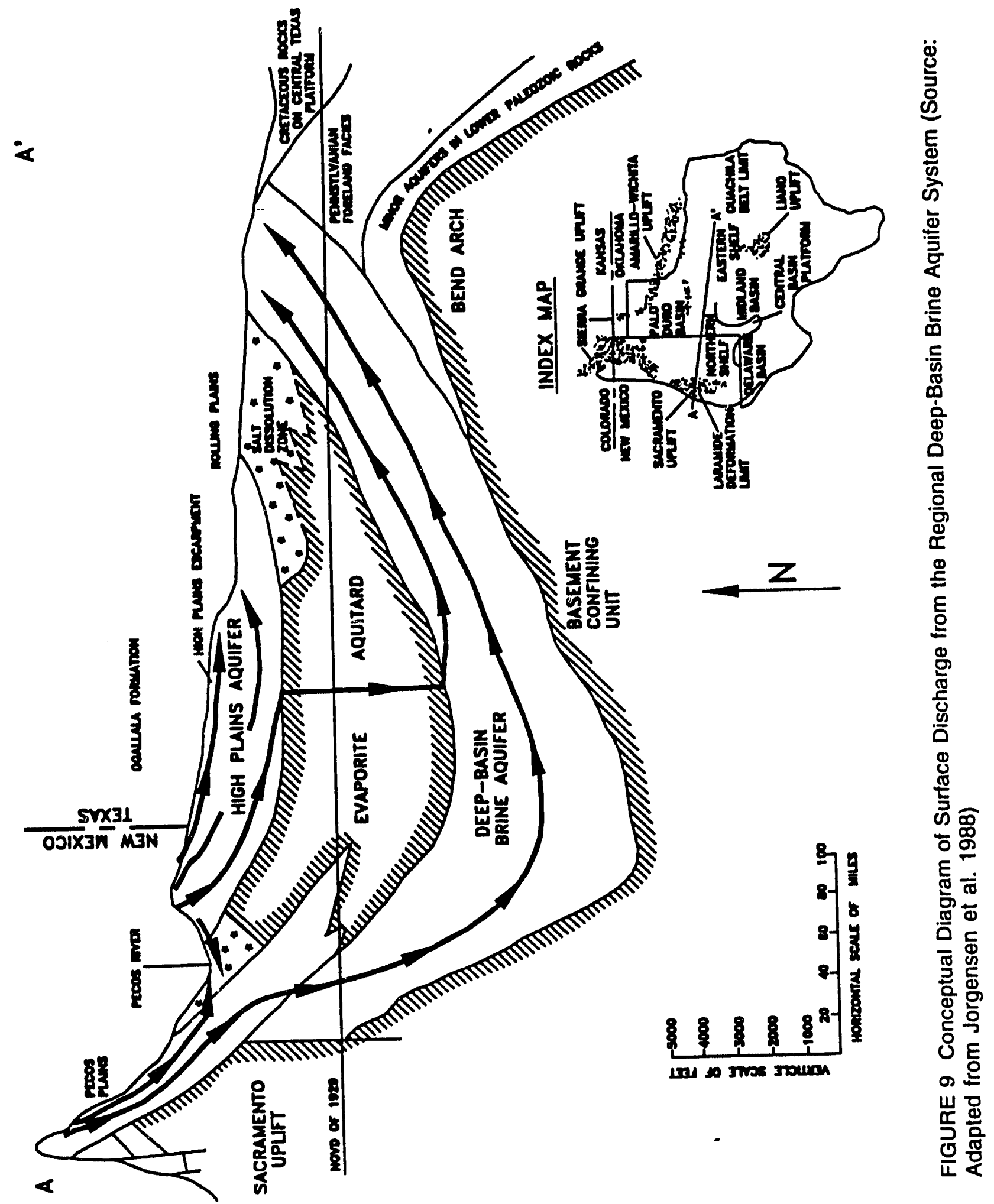


(Figure 7). The Wichita, which outcrops in Throckmorton County, about 60 mi northwest of Fort Wolters, consists mainly of gray and red shale, with minor amounts of limestone, sandstone, siltstone, conglomerate, and coal. It yields small quantities of fresh to slightly saline water in the outcrop area.

The Cisco group outcrops in Young County, about $25 \mathrm{mi}$ from Fort Wolters, and underlies the Wichita group to the northwest. The Cisco group is composed of alternating beds of shale, sandstone, limestone, and conglomerate, and it yields small to moderate quantities of fresh to moderately saline water.

The Strawn group, which outcrops in Parker and Palo Pinto counties, is composed of alternating beds of shale, conglomerate, and sandstone, with minor amounts of limestone and coal. The Strawn yields small quantities of slightly to moderately saline water from sandstone and conglomerate units in and near the outcrop area.

Within the entire Rolling Prairies physiographic section, groundwater sources in 1988 supplied a total of 110,077 acre-feet of water for irrigation, 8,515 acre-feet of water for mining, 7,534 acre-feet of water for rural domestic consumption, 7,028 acre-feet for public supply, 2,752 acre-feet for livestock, and 726 acre-feet for manufacturing (Duffin and Beynon 1992).

By a wide margin, irrigation represents the largest category of groundwater use within the Rolling Prairies section. In Palo Pinto County, however, only 5 acre-feet of groundwater were supplied for irrigation in 1989, whereas 575 acre-feet of surface water were used to irrigate crops in the same year (Duffin and Beynon 1992). Approximately 86\% (95,613 acre-feet) of the groundwater used for irrigation in 1988 was produced from the Seymour formation, a Quaternary age aquifer that is not found in Parker County or Palo Pinto County. The Seymour aquifer supplied about $80 \%$ of the total groundwater pumped in the Rolling Prairies section for all use categories in 1988.

Figure 10 shows the locations of wells within a 4-mi radius of Fort Wolters in Parker County (Nordstrom 1982). The areal extent of Fort Wolters causes some ambiguity about the center point chosen for the 4-mi-radius inclusion zone. The zone drawn on Figure 10 was centered on the northern portion of Fort Wolters to demonstrate that the only public water supply weil in the vicinity, that belonging to the town of Whitt, is considerably more than $4 \mathrm{mi}$ from the locations of TXARNG maintenance activities or former Nike operations. As mentioned before, the town of 


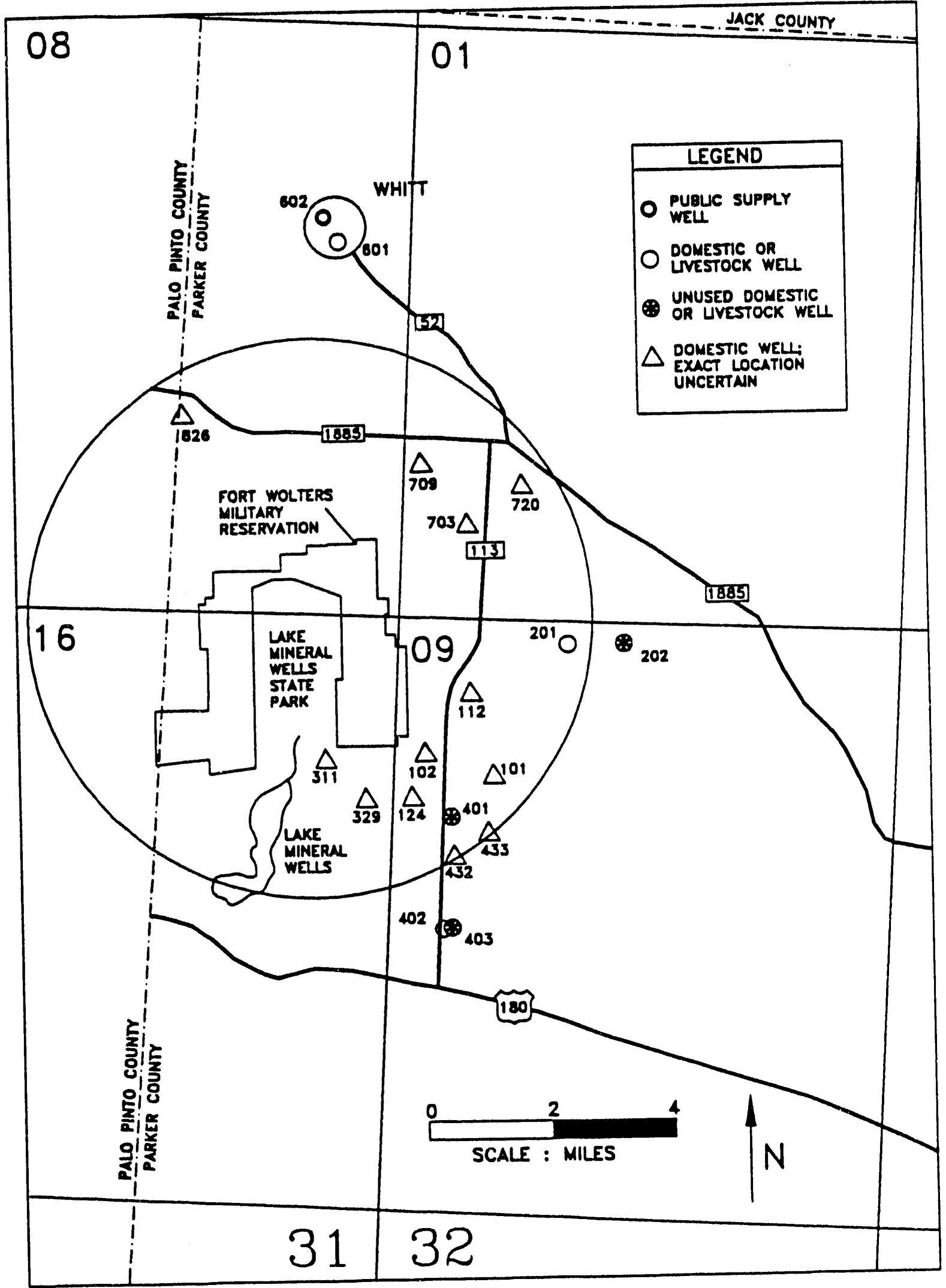

FIGURE 10 Locations of Water Wells in the Vicinity of Fort Wolters (Source: Adapted from Nordstrom 1982) 
Whitt taps the Strawn formation for public water. The Whitt public well is reported to produce $122 \mathrm{gal} / \mathrm{min}$, and in 1975 it was found to have $1,974 \mathrm{mg} / \mathrm{L}$ of total dissolved solids (Nordstrom 1982).

Table 5 summarizes pertinent information on the wells shown in Figure 10. The wells are numbered according to a system originally developed by the Texas Water Commission, which is now in use statewide. The system is based on the division of the state into 1-deg quadrangles of latitude and longitude, with repeated division of these quadrangles into smaller and smaller units. Each 1-deg quadrangle is subdivided into 64 quadrangles ( $7.5 \mathrm{~min}$ each), and these quadrangles are further subdivided into 9 quadrangles $(2.5 \mathrm{~min}$ each). The 1-deg quadrangles are identified with large open-block numbers on Figure 10. The 7.5-min quadrangles are numbered in their respective upper left-hand corners. The 2.5-min quadrangles are not shown on Figure 10.

Wells are identified by a two-letter county prefix, which in this case is UP for Parker County, and a seven-digit number. The first two digits identify the 1-deg quadrangle in which the well is located (either 31 or 32 for this report). The third and fourth digits identify the appropriate 7.5-min quadrangle, and the fifth digit identifies the appropriate 2.5 -min quadrangle. The last two digits identify the particular well within the 2.5 -min quadrangle. As an example, the Whitt public well is designated UP-31-08-602, meaning (reading right to left) that it is the second well in the sixth 2.5 -min quadrangle in the eighth $7.5-\mathrm{min}$ quadrangle in the 31 st 1 -deg quadrangle in Parker County.

Oil production operations may have adversely affected groundwater quality (Duffin and Beynon 1992). Oil fields in the area (Figure 1) produce significant amounts of brine in addition to the desired hydrocarbons. Probably the greatest single cause of groundwater contamination was the disposal of oil field brines into unlined surface pits before the statewide "no pit" order was issued by the Texas Railroad Commission, effective January 1, 1969. Emergency pit waivers are still granted in certain cases, although the permitting procedure became much more restrictive in 1985. Even so, most pits that are permitted for emergency use (as when a tank farm is struck by lightning) are still not required to have liners. 
TABLE 5 Water Wells in the Vicinity of Fort Wolters

\begin{tabular}{|c|c|c|c|c|c|}
\hline Well Number & Owner & $\begin{array}{l}\text { Depth of } \\
\text { Well } \\
(\mathrm{ft})\end{array}$ & Usea & $\begin{array}{l}\text { Production } \\
\text { Rate } \\
\text { (gal/min) }\end{array}$ & $\begin{array}{c}\text { Total Dissolved } \\
\text { Solids } \\
(\mathrm{mg} / \mathrm{L})\end{array}$ \\
\hline UP-31-08-601 & Whitt Public School & 60 & $D$ & - & 989 \\
\hline-602 & City of Whitt & 410 & $P$ & 122 & 1,974 \\
\hline UP-32-09-201 & H.B. Jennings & 35 & $N$ & - & 577 \\
\hline-202 & E.A. Ponds & 90 & $N$ & - & 863 \\
\hline .401 & Garner Consolidated School & 30 & $N$ & - & 1,019 \\
\hline .402 & W.L. Jenkins & 125 & $N$ & 15 & - \\
\hline-403 & $\cdot$ & 106 & $D$ & 15 & - \\
\hline UP-31-08-826 & J. Cotton & 400 & $D$ & 20 & - \\
\hline UP-31-16-311 & B.J. Mayhar & 64 & $D$ & 14 & - \\
\hline-329 & T. Herndon & 140 & $\cdot$ & 15 & - \\
\hline UP-32-01-703 & R. Long & 400 & D & 12 & - \\
\hline-709 & Bryant's Horse Ranch & 430 & D & - & - \\
\hline .720 & Chester & 130 & D & - & - \\
\hline UP-32-09-101 & H. Easton & 80 & $D$ & 4 & - \\
\hline .102 & J. Lee & 140 & $D$ & 6 & - \\
\hline-112 & T. Fina & 140 & D & - & - \\
\hline-124 & Hammond & 170 & $D$ & 8 & - \\
\hline UP-32-09-432 & J. Cates & 200 & $D$ & - & - \\
\hline-433 & M. Blaird & 160 & $D$ & - & - \\
\hline
\end{tabular}

a Abbreviations: $D$, domestic; $P$, public supply; $N$, not in use.

Sources: Nordstrom (1982) and TWC (1993).

\subsubsection{Sensitive Environments}

The Fort Wolters property surrounds the Lake Mineral Wells State Park on three sides. Drainage is southerly through Rock Creek and Rippy Branch to Lake Mineral Wells. This surface water impoundment is the source of drinking water for the city of Mineral Wells and nearby towns.

Fort Wolters lies within the West Cross Timbers vegetation zone (NGB 1978; Gore and Reagan 1989). The predominant growth is post oak and blackjack oak with an undergrowth of brush and grass. The trees are scrubby, of small size, and unsuited for most uses other than firewood. Common shrubs in the area are obelia, grandiflora, holly, ligustrum, nandina, honeysuckle, and yucca. Aquatic plants in the area include algae, busy pondweed, coontail, fanworth, water weed elodea, water star grass, duckweed, yellow water lily, white water lily, 
American lotus, cattails, bulrush, rush, water primrose, water smartweed, arrowhead, black willow, and button brush. The climax plant community is a post oak, blackjack oak savanna that has an understory of medium and tall grasses. Little bluestem, indian grass, big bluestem, and side oats grama are dominant. Approximate species composition, by weight, is 3()$\%$ little bluestem; $10 \%$ big bluestem; $10 \%$ indian grass; $10 \%$ side oats grama; $5 \%$ silver bluestem; $5 \%$ Scribner panicum; 5\% Texas wintergrass; $5 \%$ Arizona cottontop; $10 \%$ post oak, blackjack oak, elm, hackberry, skunkbush sumac, and prickly ash; and 10\% Engelmann daisy, bundleflower, prairie clover, western ragweed, and dotted gayfeather.

Principal land animals found in the area are armadillos, squirrels, rabbits, opossums, raccoons, foxes, and bobcats. Ducks and other migratory waterfowl pass through the area in late fall and early spring but seldom stop for more than short periods. A large variety of song birds either resides in or migrates through the area. The birds include bluejays, cardinals, sparrows, mockingbirds, mourning doves, blackbirds, meadowlarks, bobwhite quail, and redwing blackbirds. Principal fish species tound in the area are catfish, carp, sunfish, and bass. Most of the impoundments in the area offer good lish habitat. Shelltish found in the area are mussels and freshwater clams. Amphibians are frogs and salamanders.

Whether habitats of endangered or threatened species are located on or near the site is unknown (TXARNG 1992b). An earlier survey by the Texas Parks and Wildlife Department reported no evidence of rare or endangered species inhabiting the area (NGB 1978). 


\section{Environmentally Significant Operations}

Maintenance activities performed at the Fort Wolters property as part of TXARNG training operations require the use of hazardous materials and could result in the release of hazardous waste. Also of concern is the potential for hazardous waste to be present on the site as a result of former Nike missile program operations, or in the form of original construction materials, or as a result of unauthorized disposal of waste on the property.

The PA team from Argonne identified six ESOs at the Fort Wolters TXARNG property. These ESOs are (1) fuel storage and dispensing, (2) storage of hazardous materials/hazardous waste, (3) vehicle/equipment washing, (4) former Nike missile program operations, (5) use of hazardous construction materials, and (6) unauthorized disposal of waste. Each ESO is described below.

\subsection{Fuel Storage and Dispensing}

Fuel storage and dispensing are currently performed at Fort Wolters at the UTES 2 and at the exercise area maintenance facility (the former Nike MLA). Fuel storage and dispensing also occurred at the former Nike IFC area when that facility was still in operation. Release of fuel could result from tank leakage or rupture, a fuel line break, or an inadvertent spill during tank lilling. Table 6 is a summary of current and former fuel storage tanks at the TXARNG property. Not included in the table are two 600-gal fuel storage pods for gasoline (MOGAS) located at the exercise area maintenance facility, which are available for use during field training exercises.

\subsection{Storage of Hazardous Materials/Hazardous Waste}

Maintenance activities performed at the Fort Wolters UTES 2 and at the exercise area maintenance facility as part of normal operations require the use and storage of limited quantities of hazardous materials and the generation and storage of hazardous waste. Materials are segregated by type and are stored in designated storage areas. The UTES 2 is the primary maintenance facility at Fort Wolters, and the majority of hazardous materials are at that location. Used oil (crankcase oil, gear lubricants, metal-working lubricants, hydraulic oils, cutting oils, etc.) and cleaning solvents (Safety Kleen) are recycled. Waste oil is stored at the UTES 2 in a 1,000-gal 
TABLE 6 Summary of Fuel Storage Tanks at Fort Wolters

\begin{tabular}{|c|c|c|c|}
\hline $\begin{array}{l}\text { Fuel Tank } \\
\text { Volume } \\
\text { (gal) }\end{array}$ & $\begin{array}{l}\text { Type of } \\
\text { Storage }\end{array}$ & Type of Fuel & Tank Status \\
\hline \multicolumn{4}{|c|}{ Unit Training Equipment Site 2} \\
\hline $\begin{array}{r}14,000 \\
8,000 \\
6,000\end{array}$ & $\begin{array}{l}\text { Aboveground } \\
\text { Underground } \\
\text { Underground }\end{array}$ & $\begin{array}{l}\text { Diesel fuel } \\
\text { Diesel fuel } \\
\text { Gasoline }\end{array}$ & $\begin{array}{l}\text { In use } \\
\text { Removed in } 1992 \\
\text { Removed in } 1992\end{array}$ \\
\hline \multicolumn{4}{|c|}{ Former Nike Missile Launch Area } \\
\hline $\begin{array}{l}5,000 \\
5,000 \\
6,000 \\
4,000\end{array}$ & $\begin{array}{l}\text { Underground } \\
\text { Underground } \\
\text { Underground } \\
\text { Underground }\end{array}$ & $\begin{array}{l}\text { Diesel fuel } \\
\text { Gasoline } \\
\text { Diesel fuel } \\
\text { Gasoline }\end{array}$ & $\begin{array}{l}\text { In use } \\
\text { In use } \\
\text { Removed in } 1988 \\
\text { Removed in } 1988\end{array}$ \\
\hline \multicolumn{4}{|c|}{ Former Nike Integrated Fire Control Area } \\
\hline $\begin{array}{l}6,000 \\
4,000\end{array}$ & $\begin{array}{l}\text { Underground } \\
\text { Underground }\end{array}$ & $\begin{array}{l}\text { Diesel fuel } \\
\text { Gasoline }\end{array}$ & $\begin{array}{l}\text { Removed in } 1988 \\
\text { Removed in } 1988\end{array}$ \\
\hline
\end{tabular}

Source: Hall (1988).

UST constructed of fiberglass with steel piping. Throughput of the waste oil is approximately 1,200 gal per month (Dennis 1993). Table 7 is an inventory of hazardous materials typically stored at the UTES 2. Table 8 is an inventory of hazardous materials typically stored at the exercise area maintenance facility.

\subsection{Former Nike Missile Program Operations}

Hazardous waste could be present on the property as a result of the operation of the former Nike missile base. Generic information on the Nike missile program has been compiled by both the Army Corps of Engineers (LETC 1986) and the former U.S. Army Toxic and Hazardous Materials Agency (ESE 1984). Some information about the Nike defense program is available, but much remains classified for reasons of national security. Nevertheless, taken together, these two reports represent the most complete assemblage of information on the Nike missile program from an environmental perspective. 
TABLE 7 Hazardous Materials Inventory at the UTES 2

\begin{tabular}{|c|c|c|}
\hline Materlal & Type of Container & $\begin{array}{l}\text { Maximum } \\
\text { Amount Storec }\end{array}$ \\
\hline $\begin{array}{l}\text { Used oll } \\
\text { Used solvents } \\
\text { Lubricating oil (new) } \\
\text { Brake fluld (new) } \\
\text { Brake fluid (used) } \\
\text { Paints/thinners (new) } \\
\text { Paints/thinners (old) } \\
\text { Solvents (new) } \\
\text { Batterles (new) } \\
\text { Batterles (used) } \\
\text { Battery acld } \\
\text { Coolant/antifreeze (new) } \\
\text { Coolant/antlifeeze (used) } \\
\text { Other oll (new) }\end{array}$ & 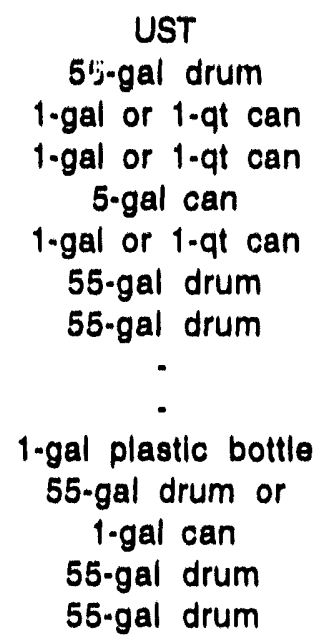 & $\begin{array}{c}1,000 \mathrm{gal} \\
2 \mathrm{drums} \\
250 \mathrm{gal} \\
4 \mathrm{gal} \\
5 \mathrm{gal} \\
30 \mathrm{gal} \\
1 \text { drum } \\
3 \text { drums } \\
18 \text { batteries } \\
8 \text { batteries } \\
24 \text { gal } \\
3 \text { drums }\end{array}$ \\
\hline
\end{tabular}

Source: TXARNG (1987).

The Fort Wolters Nike battery consisted of two distinct operating units, the MLA and the IFC area. The MLA was approximately 8 acres in size, while the IFC was approximately 14 acres (Hall 1988). The two areas were separated by a distance of about $3,000 \mathrm{ft}$, with a line of sight between them for communication and tracking purposes. Barracks facilities were incorporated into the IFC area.

Of the two operating areas composing the missile battery, the MLA clearly represented the greater potential for environmental contamination. At Fort Wolters, missile assembly was conducted in Building 1206. Missile components were shipped to the site in metal canisters and wooden crates. Solvents used for missile preparation and cleaning included petroleum distillates, chlorinated solvents, and small amounts of alcohols. Large quantities of certain solvents would evaporate during use; this particularly applies to chlorinated solvents such as carbon tetrachloride. Spills to the ground surface would evaporate rapidly in the dry Texas soils.

Missile fueling and warheading were conducted apart from the assembly building. Fueling with unsymmetrical dimethylhydrazone (UDMH), inhibited red fuming nitric acid (IRFNA), aniline, furfuryl alcohol, and ethylene oxide presented fire and personnel safety hazards, so their 
TABLE 8 Hazardous Materials Inventory at the Exercise Area Maintenance Facility

\begin{tabular}{lll}
\hline \multicolumn{1}{c}{ Material } & $\begin{array}{c}\text { Amount } \\
\text { Stored }\end{array}$ & $\begin{array}{c}\text { Consumption } \\
\text { Rate }\end{array}$ \\
\hline Super-Sol grease trap emulsifler & $3.6 \mathrm{gal}$ & $6 \mathrm{gal} / \mathrm{yr}$ \\
lce machine coil cleaner & $4 \mathrm{gal}$ & $2 \mathrm{gal} / \mathrm{yr}$ \\
Roundup herbicide & $2.5 \mathrm{gal}$ & $5 \mathrm{gal} / \mathrm{yr}$ \\
Flounce hand soap & $13 \mathrm{gal}$ & $1 \mathrm{gal} / \mathrm{mon}$ \\
Wescodyne detergent & $3 \mathrm{gal}$ & $1 \mathrm{gal} / \mathrm{mon}$ \\
Seal All floor cleaner & $34 \mathrm{gal}$ & $4 \mathrm{gal} / \mathrm{yr}$ \\
So-Sure paint & $76 \mathrm{cans}$ & $4 \mathrm{cans} / \mathrm{mon}$ \\
Pine Oll disinfectant & $1,632 \mathrm{oz}$ & $32 \mathrm{oz} / \mathrm{wk}$ \\
Clenzol degreaser & $768 \mathrm{oz}$ & $64 \mathrm{oz} / \mathrm{mon}$ \\
Big-D cleaner & $405 \mathrm{oz}$ & $15 \mathrm{oz} / \mathrm{mon}$ \\
WHC hand cleaner & $55 \mathrm{lb}$ & $5 \mathrm{lb} / \mathrm{we \theta k}$ \\
TOBO toilet cleaner & $1,312 \mathrm{oz}$ & $128 \mathrm{oz} / \mathrm{mon}$ \\
Bippy metal cleaner & $1,696 \mathrm{oz}$ & $160 \mathrm{oz} / \mathrm{mon}$ \\
Glass cleaner & $288 \mathrm{oz}$ & $128 \mathrm{oz} / \mathrm{mon}$ \\
Floor stripper & $22 \mathrm{gal}$ & $2 \mathrm{gal} / \mathrm{mon}$ \\
Clenzol degreaser & $14 \mathrm{gal}$ & $2 \mathrm{gal} / \mathrm{mon}$ \\
Limesol lime remover & $16 \mathrm{gal}$ & $4 \mathrm{gal} / \mathrm{yr}$ \\
Mel-Tex floor finish & $33 \mathrm{gal}$ & $22 \mathrm{gal} / \mathrm{mon}$ \\
Bright-Klear detergent & $80 \mathrm{lb}$ & $5 \mathrm{lb} / \mathrm{mon}$ \\
& & \\
\hline
\end{tabular}

Source: TXARNG (1991).

use was strictly controlled. Turn-in to the depot for official disposal, as a means of recycling to maintain fresh fuel on site, was likely to have been strictly practiced. Environmental contamination, if it occurred, would probably have been be limited to incidental releases.

Missile maintenance was performed within the bermed area south of Building 1207. A portion of the berm was removed in 1976 when the site was redeveloped by the TXARNG. Maintenance most typically involved removal of corrosion, painting, and replacing of hydraulic fluid. Removal of corrosion from metal parts was conducted with at least three types of cleaners. Phosphoric acid in alcohol was used for metal parts, and alodine powder was used in water for minor cleaning. Most significant was the use of chromates in the form of chromium trioxide and sodium dichromate. Chromium trioxide, a solid material available in 5-lb containers, was dissolved in water and used to wash magnesium and steel. Sodium dichromate, also a solid, was dissolved in acids to form a pickling solution, into which the metal parts were dipped. Solutions used for decorrosion were washed into sumps and allowed to leach into the soil. The acid 
neutralization leaching pit identified in the 1958 site plan of the facility, in the vicinity of the current vehicle/tank washrack, is no longer exposed.

Painting of missile components involved the use of chromium and lead. Zinc chromate was used to prime magnesium parts after cleaning; lead-based paint was used for steel. The majority of paint would have been consumed. The remainder was probably discarded via POL collection or as solid waste. Missile hydraulic fluid was replaced regularly. Unused hydraulic fluids would have been discarded via POL collection or dumped on the site.

The primary mission of the Nike IFC facility was radar tracking and missile guidance. Radar did not require extensive use of chemicals. Maintenance of radar was mostly electrical, using relatively small amounts of solvent for cleaning. The High-Power Acquisition Radar (HIPAR) used a coolunt pumping system consisting of an ethylene glycol circulating system and a pump. The ethylene glycol was replaced annually. The pump was oil lubricated. Paint was the most significant chemical used on the radar systems. Except for fuel, paint represented the greatest volume of hazardous material present at the IFC tacility. Common paints of the Nike period used lead (20-30\%) as a pigment. Most paint was consumed, leaving little waste for disposal. Unused paint was discarded either via POL collection or as solid waste.

Pesticides and herbicides had variable use at former Nike facilities. Pesticides were used as needed. Herbicides were used to maintain vegetation-free areas around site perimeters, primarily for fire control.

The former Nike MLA and IFC area both had underground fuel storage facilities as indicated in Table 6. Each facility had a 6,000-gal UST for storage of diesel tuel used to power electric generators, as well as a 4,000-gal UST for storage of gasoline for vehicles. All four tanks were removed in 1988.

Documentation regarding deactivation of the Fort Wolters Nike base was unavailable for this PA, although a site plan of the former MLA was available (USACE 1958). No evidence of an on-site landfill or other waste disposal area was seen during the site survey. Table 9 contains a general inventory of hazardous materials present at former Nike facilities that were required for maintenance and servicing of missile launching and control operations (LETC 1986). 


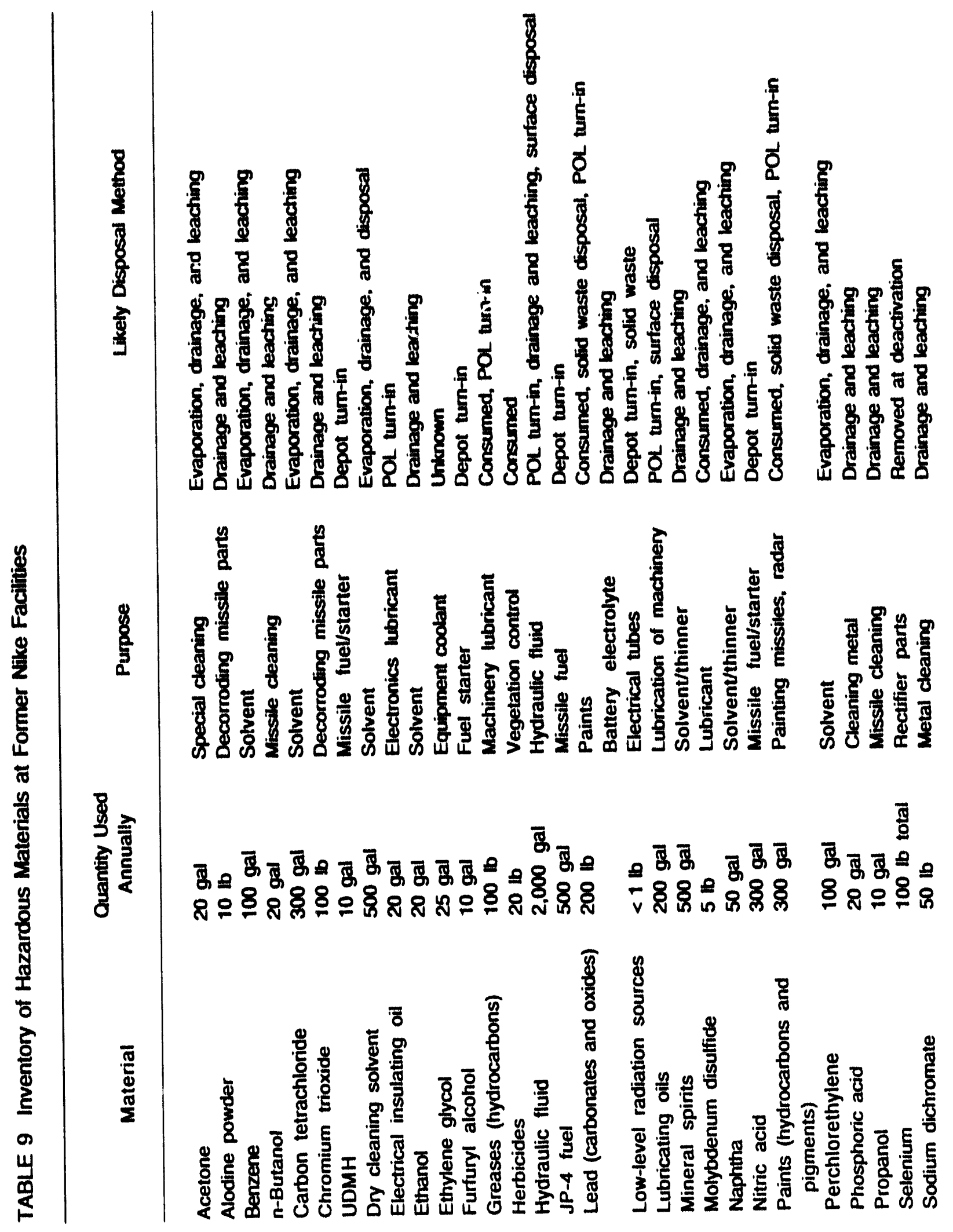




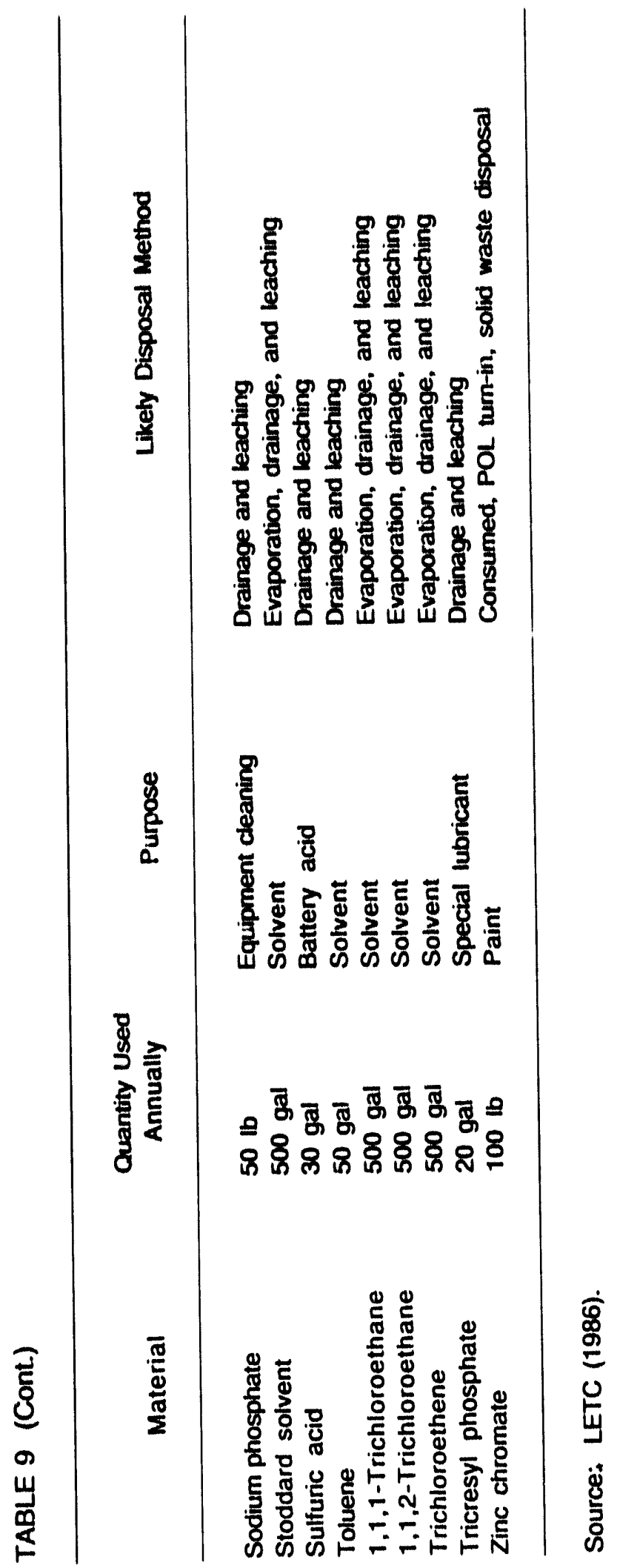




\subsection{Use of Hazardous Construction Materials}

Two materials now recognized as hazardous that were typically used as construction materials during the years when Fort Wolters was constructed as an army training center and Nike facility are PCBs and asbestos. Carcinogenic PCBs were used as a component of dielectric fluid in transformers. Eventual deterioration of sealed units could have resulted in rupture of the unit, with the subsequent release of small quantities of the carcinogen. PCBs are relatively immobile in soils, and contamination, if release occurred, would be limited to the immediate vicinity of the leaking transformer. Transformers containing PCBs are present at the facility, and surface soil contamination has occurred as a result of a leaking transformer. See Section 4.3 for further discussion.

Asbestos was in widespread use in past years as a building/equipment insulation material and as a component of some construction materials, including floor and ceiling tiles and wall siding. Asbestos still present on the site in buildings and on piping and ductwork could constitute a health hazard for site workers. An asbestos survey performed in early 1993 confirmed the presence of asbestos in some building construction materials (USACE 1993). See Section 4.4 for further discussion.

\subsection{Unauthorized Disposal of Waste}

In two areas, unauthorized disposal of waste materials is known to have occurred on the property. The approximate locations of Waste Disposal Area 1 and Waste Disposal Area 2 are shown in Figure 11 (Dennis 1993). Waste Disposal Area 1, containing metal sheeting, shingles, and other debris, covers an area approximately $300 \mathrm{ft}$ long and $10 \mathrm{ft}$ wide (as estimated from the air, where the view of the disposal area is partially obscured by vegetation). Waste Disposal Area 2 is a small area of trash discarded by an unknown party, probably a trespassing civilian. This waste material appears to be prinarily household waste and construction debris. 


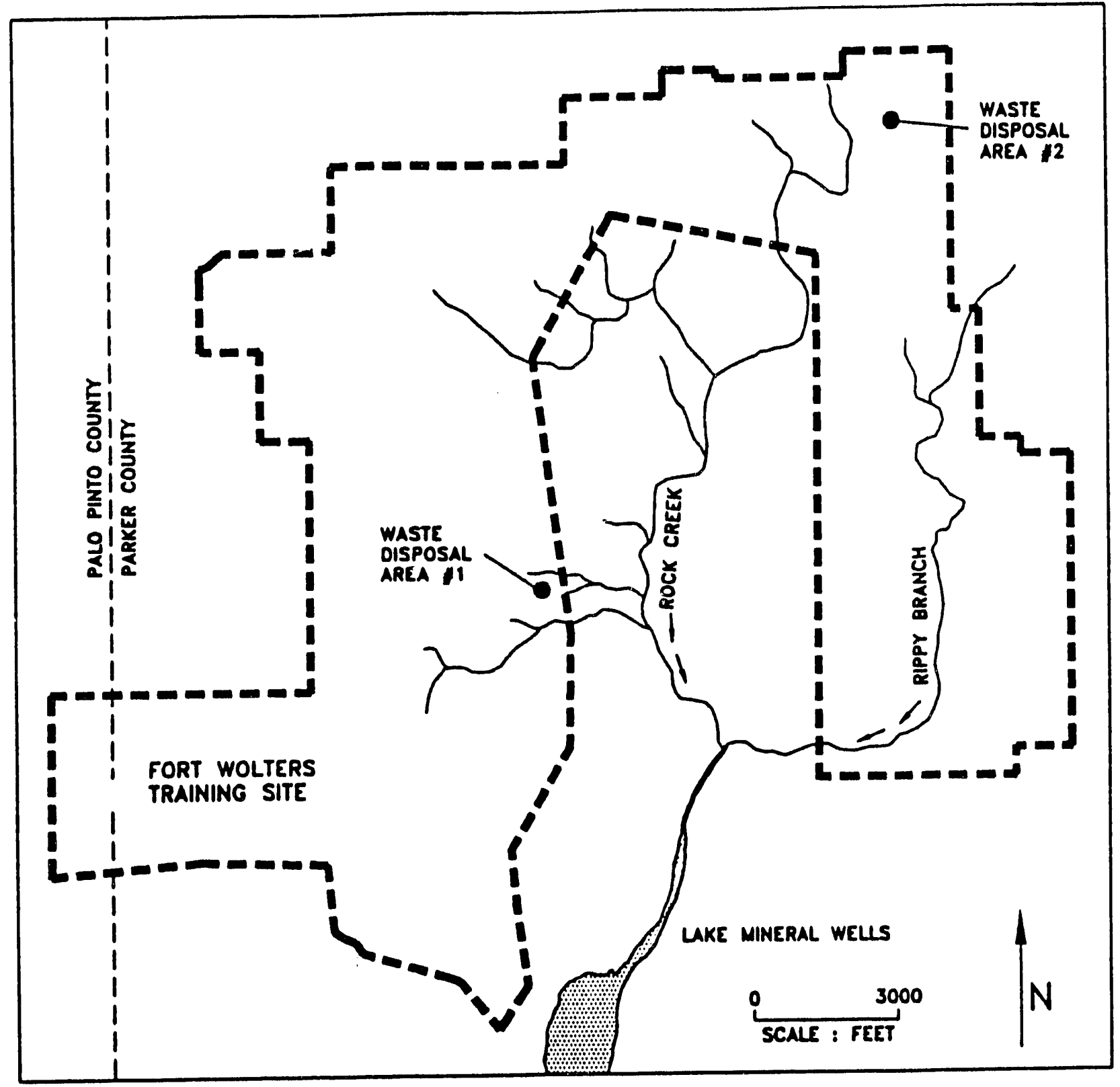

FIGURE 11 Approximate Locations of Unauthorized Waste Disposal Areas (Source: Dennis 1993) 


\section{Known and Suspected Releases}

\subsection{Releases to Groundwater}

Because of the age of the four USTs used as part of operations at the former Nike MLA and IFC area, tank deterioration and consequent leakage over time was highly likely. These four USTs were removed in 1988. Inspection at the time of excavation revealed that the tanks had been laid in hollowed-out rocky areas and that the lack of moisture had prevented corrosion. No noticeable leakage to the subsurface had occurred.

In 1992, the USTs at the UTES 2 facility were discovered to be leaking at the piping connection points to the dispenser. The USTs were removed, and 24 drums of soil (55 gal each) were excavated during cleanup. The Texas Water Commission authorized removal of the excavated soil on June 9, 1992 (Dennis 1993).

Waste disposal activities at the former Nike MLA and IFC facilities cannot be verified. Most materials would have been consumed during operations, so that only a fraction would have been disposed as waste. This is especially the case at the former IFC area. The acid leaching pit at the former MLA, the Nike location of greater chemical use, was probably used for disposal of waste solvents and acids. This area has subsequently been covered by the tank washrack. Water sampling performed in the three missile silos in 1991 provided no evidence of contamination at those locations (STS 1991).

\subsection{Releases to Surface Water}

The TXARNG maintenance activities are located in areas some distance from surface water streams, making releases to surface waters from those areas unlikely. Runoff from maintenance areas that is not directed to the sanitary sewer system will infiltrate surface soils before it migrates to surface water streanis.

The two unauthorized waste disposal areas are located near surface water streams. Drainage from the area of Waste Disposal Area 1 flows to Rock Creek. Drainage from Waste Disposal Area 2 flows toward Rippy Branch. Both streams feed Lake Mineral Wells. 


\subsection{Rel ases to Soil}

Fuel represents the greatest volume of hazardous materials historically used at the property, and the most significant releases of hazardous materials to surface soils are likely to have occurred as a result of surface runoff from fueling operations. Such releases can occur either during refilling of the USTs or during fuel dispensing to vehicles. Drainage from current fuel locations is directed through oil-water separators. With the construction of the taris vehicle wash facility at the UTES 2, the tank wash area at the exercise area maintenance facility is seldom used. Drainage from the tank wash area at the exercise area maintenance facility is not directed through an oil-water separator, and surface runoff is partially to the surrounding soil surface. Herbicides have been applied to site areas to control vegetation. No staining of surface soils and no areas of stressed vegetation were evident during the site survey.

Deterioration of a sealed transformer located at the former Nike IFC site caused the unit to rupture and led to the subsequent release of a small quantity of PCB-contaminated dielectric fluid to surface soils in approximately 1987, according to site personnel (Dennis 1993). Contaminated soils were excavated and removed by the TU Electric Company. Transformers on the site have been analyzed for PCB contamination (Shields 1992; Tryce 1992). Table 10 is a summary of transformers on the site and their PCB status.

\subsection{Releases to Air}

Routine operations performed as part of current TXARNG activities or during the former Nike IFC activities did not result in the release of significant quantities of hazardous materials to the air. Fugitive dust and emissions that result from the use of vehicles during current TXARNG training exercises are discounted as an ESO.

A survey performed in early 1993 for the U.S. Army Corps of Engineers confirmed the presence of asbestos in certain building materials, including floor tiles and mastic, asphalt roofing mastic and roofing felt, tar patching, wall mastic, Transite board, window putty, and insulation materials (USACE 1993). A total of 126 bulk samples were collected from 27 of the 42 buildings inspected at the Fort Wolters property. Thirty-eight of the samples were identified as asbestoscontaining materials (ACMs). Table 11 summarizes the samples of building construction materials collected that contained asbestos. Friable ACMs can be hazardous to building occupants because 
TABLE 10 Summary of Transformers at Fort Wolters

\begin{tabular}{|c|c|c|}
\hline Location & $\begin{array}{l}\text { Transformer } \\
\text { Identification }\end{array}$ & $\begin{array}{l}\text { Size } \\
\text { (kVA) }\end{array}$ \\
\hline \multicolumn{3}{|c|}{$\begin{array}{l}\text { TU Electric Co. Transformers } \\
\text { (PCB concentrations } 0 \text { ppm to }<50 \mathrm{ppm})\end{array}$} \\
\hline Building 1200 & $3 n 03752$ & 50.0 \\
\hline Building 1200 & 3008111 & 167.0 \\
\hline Building 1200 & 3008110 & 167.0 \\
\hline Building 742 & 3007817 & 15.0 \\
\hline Building 742 & 3008075 & 15.0 \\
\hline Building 742 & 3007813 & 15.0 \\
\hline Building 741 & 3007928 & 37.5 \\
\hline Building 741 & 3007929 & 37.5 \\
\hline Building 741 & 3007930 & 37.5 \\
\hline Building 738 & 7442042 & 25.0 \\
\hline Stage Field 1 & 3007907 & 10.0 \\
\hline Stage Field 2 & 3003539 & 5.0 \\
\hline Building 630 & 3007915 & 37.5 \\
\hline Building 630 & 3007916 & 15.0 \\
\hline Firing range & 3007913 & 15.0 \\
\hline \multicolumn{3}{|c|}{$\begin{array}{l}\text { TU Electric Co. Transformers } \\
\text { (PCB concentrations } 50 \mathrm{ppm} \text { to }<499 \mathrm{ppm})\end{array}$} \\
\hline Building 1100 & 8842015 & 25.0 \\
\hline Building 1100 & 8842016 & 25.0 \\
\hline Building 1100 & 8842017 & 25.0 \\
\hline Building 604 & 8342078 & 10.0 \\
\hline Building 620 & 8742031 & 15.0 \\
\hline Building 620 & 8742032 & 15.0 \\
\hline Building 620 & 8742033 & 15.0 \\
\hline Building 621 & 8642138 & 10.0 \\
\hline Building 594 & 8842119 & 10.0 \\
\hline \multicolumn{3}{|c|}{$\begin{array}{l}\text { TXARNG Transformers } \\
\text { (PCB concentrations }<2 \mathrm{ppm})\end{array}$} \\
\hline Building 1202 & $\begin{array}{l}\text { Exercise area maintenance } \\
\text { facility manager's office }\end{array}$ & $-a$ \\
\hline Building 1201 & $\begin{array}{l}\text { Exercise area maintenance } \\
\text { facility guardhouse }\end{array}$ & $\cdot$ \\
\hline Building 1188 & $\begin{array}{l}\text { Former Nike IFC area } \\
\text { warehouse }\end{array}$ & - \\
\hline Building 1179 & $\begin{array}{l}\text { Former Nike IFC area } \\
\text { recreation hall }\end{array}$ & $\cdot$ \\
\hline Building 1178 & $\begin{array}{l}\text { Former Nike IFC area } \\
\text { guardhouse }\end{array}$ & - \\
\hline
\end{tabular}

a Sizes of TXARNG transformers are unavailable.

Sources: Shields (1992) and Tryce (1992). 


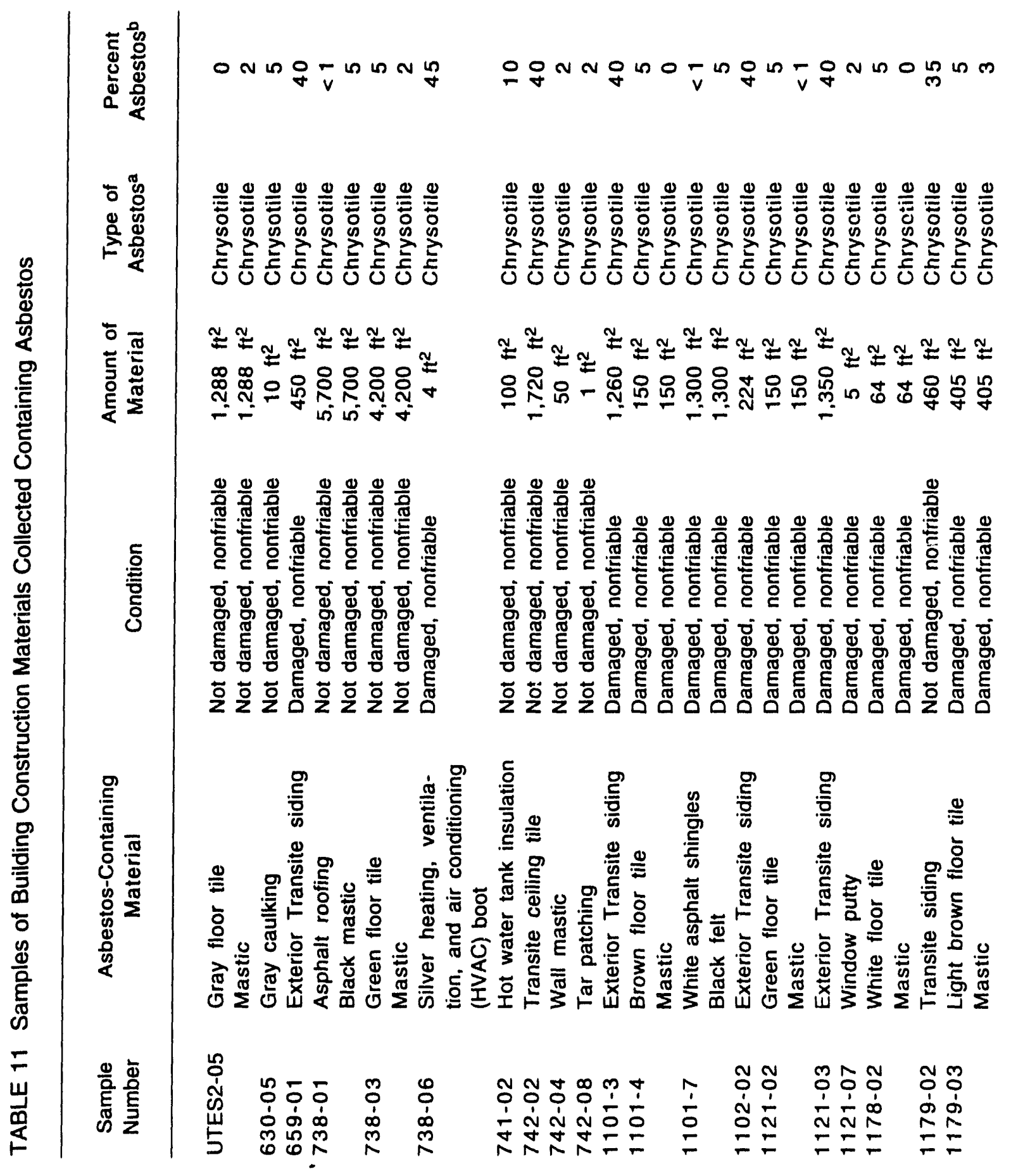




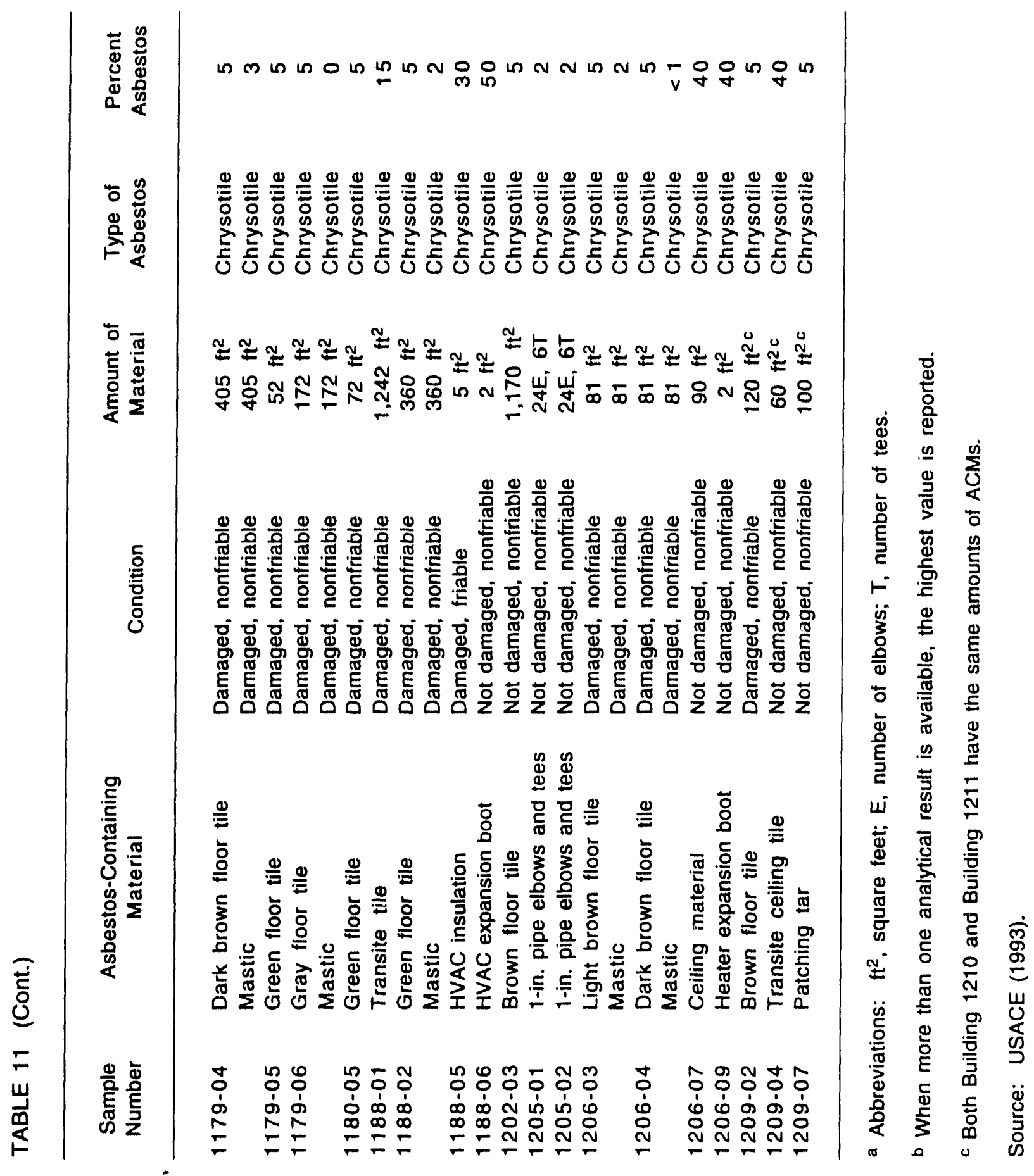


of the potential for release of asbestos fibers to the atmosphere. Friable ACMs were identified only in Building 1188, in the former Nike IFC area. Building 1188 was previously used by TXARNG personnel as a recreation hall, but it is now unused. Recommendations for abatement of the friable and nonfriable ACMs were included in the survey report (USACE 1993).

\subsection{Other Releases}

Training activities at the TXARNG property, including the operation of tanks and lowflying aircraft and weapons fire, result in increased noise levels. Fire or explosion could result from an accident involving a vehicle or aircraft assigned to the unit. Low-level radiation sources in minute amounts were used in electronic tubes in Nike missile IFC equipment; release, if any, would have been negligible. 


\section{Human and Environmental Receptors}

\subsection{Groundwater}

Groundwater is available in the vicinity of Fort Wolters in the Paleozoic freshwater-bearing formations of the Wichita group of the Permian unit and the Cisco group of the Pennsylvanian unit, as discussed in Section 2.5.4. Nearby populations, including the city of Mineral Wells and nearby towns, obtain their drinking water from surface water resources. Upgradient of the TXARNG property, outside the 4-mi radius of concern, the town of Whitt uses groundwater in its public water supply.

\subsection{Surface Water}

Drainage in maintenance areas of the property, where hazardous materials are used and stored and where the potential exists for release of hazardous waste, is directed to the sanitary sewer system. Maintenance areas are some distance from surface streams, and release of contaminants from the maintenance areas via the surface water pathway is unlikely.

Surface drainage in the maneuver areas is southward, to Lake Mineral Wells. Tributaries within the TXARNG training areas feed Rock Creek and Rippy Branch, which then flow south to Lake Mineral Wells. The two unauthorized waste disposal areas are located near surface drainage flows. Waste Disposal Area 1 is approximately 1 mi north of Lake Mineral Wells. Waste Disposal Area 2 is approximately $3 \mathrm{mi}$ north of the lake.

\subsection{Soil}

Releases of hazardous waste to surface soils as a result of current TXARNG activities, primarily as a result of vehicle fueling and washing activities, are not considered to be a significant environmental concern with respect to soil contamination. Refueling is performed on asphalt or concrete surfaces, and runoff to surface soils is prevented. The central wash area at the UTES 2 is designed to prevent runoff of waste water to the surrounding soils. 


\subsection{Alr}

Limited fugitive dust and vehicle emissions result from the use of military vehicles during training exercises. However, there are currently no permit requirements. Exposure via air of the off-site population to TXARNG-generated contamination is unlikely.

Asbestos present on the site in the form of original construction materials poses a potential health risk to building occupants. No health risk to the off-site population is suspected. The only building on the site in which friable $\mathrm{ACMs}$ were identified is no longer used.

\subsection{Other Receptors}

Access to areas of the property in which hazardous materials are used and hazardous waste is generated is restricted to TXARNG personnel and escorted visitors. Workers are appropriattely trained regarding potential hazards.

The TXARNG training operations can result in increased noise levels. Operating procedures are in place to reduce the impact to off-site areas and persons. 


\section{Preliminary Assessment Findings and Conclusions}

\subsection{Summary of Preliminary Assessment Findings}

Fort Wolters is located 3 mi east of Mineral Wells, Texas, which is in Palo Pinto County. Fort Wolters is a large TXARNG training facility, presently comprising 3,985 acres. The majority of the Fort Wolters property extends northeast into Parker County.

The federally owned Fort Wolters property has a long history of military activity dating from 1925. During World War II and for some years after, the land area used by the federal government for military training was approximately twice that now available and included a substantial cantonment area. A significant portion of the former, more extensive Fort Wolters property, essentially all of the former cantonment area, has since been redeveloped by Mineral Wells as commercial, industrial, and residential areas. Much of the central portion of the former Fort Wolters property was transferred to state and local agencies for use as parks and forest preserves. Most of the property now license $\lrcorner$ to the TXARNG remains undeveloped and is used as firing ranges and for maneuver training. Maintenance support is provided through the UTES 2. Aviation facilities include an approximately 370-acre aerial drop zone. Included in the Fort Wolters property are the former Nike-Hercules Missile Defense Program MLA and IFC area designated DF-70.

Maintenance activities performed at the Fort Wolters property as part of TXARNG training operations require the use of hazardous materials and could potentially result in the release of hazardous waste. Also of concern is the potential for hazardous waste to be present on the site as a result of former Nike missile program operations, or in the form of original construction materials, or as a result of unauthorized disposal of waste on the property. The PA team from Argonne identified six ESOs at the Fort Wolters TXARNG property. These ESOs are (1) fuel storage and dispensing, (2) storage of hazardous materials/hazardous waste, (3) vehicle/equipment washing, (4) former Nike missile program operations, (5) use of hazardous construction materials, and (6) unauthorized disposal of waste. The available information indicates that the Fort Wolters TXARNG property poses low potential risk to human health and the environment.

Groundwater is not a significant source of drinking water in the area. The removal of older USTs, including those dating from the former Nike missile base operations, and installation of drainage barriers to prevent surface runoff of TXARNG-generated contaminants reduced the 
potential for subsurface migration of contaminants to groundwater. The extent of residual subsurface contamination, if any, that may be present at the site of the waste acid pit (now covered by the concrete tank wash area) in the former Nike MLA is unknown. Much of the volatile acidsolvent cleaning solutions used to remove corrosion from missile parts evaporated during use, reducing the arnount discurded.

Surface water from Lake Mineral Wells is the source of drinking water in the vicinity of Fort Wolters. Maintenance areas where hazardous materials are used and TXARNG-generated hazardous waste is likely to be present are not located near surface water stream. feeding the lake. The two unauthorized disposal areas within the training areas are near surface drainage pathways, forming a route for contaminants that may be present to migrate beyond the property boundaries to areas of human or environmental concern.

\subsection{Recommendations for Further Action}

The prim.ary objective of the PA is to identify and evaluate ESOs that would result in either (1) immediate action, (2) site investigation, or (3) no further PA/RP action. No current TXARNG training activities at Fort Wolters are considered to have a significant adverse impact to the environment.

\subsubsection{Fuel Storage and Dispensing}

Fuel represents the highest volume of hazardous materials present on the site. The present central fueling area is at a 14,000-gal aboveground storage tank within a concrete containing basin. Older USTs, including those dating from the former Nike missile base operations, have been removed. Inspection of the former Nike USTs at the time of excavation in 1988 confirmed the integrity of those tanks. Leaking USTs at the UTES 2 were removed in 1992. Cleanup of the subsurface soils was performed under the authorization of the Texas Water Commission. No further PA/IRP action is recommended for this ESO.

\subsubsection{Storage and Use of Hazardous Materials}

Drainage from maintenance work areas is directed through oil-water separators before it enters the sanitary sewer system. Storage facilities for hazardous materials/wastes are adequate. 
Installation of a small curb (or lip) at the door of the UTES 2 battery storage building is recommended to ensure containment in the event of a release there.

\subsubsection{Vohlcle/Equipment Washing}

The tank/vehicle wash facility at the UTES 2 is the central wash urea. It is designed to prevent release of waste washwater and potential contaminants. If the tank wash area at the former UTES facility (the exercise area maintenance facility) is to be used frequently, upgrading of the washrack by the addition of an vil-water separator and drainage control is recommended.

\subsubsection{Former Nike Missile Base Operations}

Little is known about deactivation of the former Nike MLA and IFC area. As stated, USTs dating from those operations have been removed with no evidence of subsurface contamination. The volume of potentially hazardous waste fluids generated at the former IFC facility was low, and subsurface contamination at that site is not suspected. Maintenance and fueling operations performed at the former MLA could have resulted in subsurface contamination, especially at the location of the former waste acid pit. Missile maintenance operations required the use of significant quantities of solvents and acids, which were discarded at the waste acid pit now covered by the tank wash area. In the intervening years, infiltration of precipitation has probably diluted and washed away the discarded fluids. Limited subsurface soil sampling (no deeper than $20 \mathrm{ft}$ ) at the location of the former waste acid pit is recommended to confirm that no residual subsurface contamination is present. Water sampling already performed within the abandoned missile silos indicated that no contamination is present at those locations.

\subsubsection{Use of Hazardous Construction Materials}

Surveys have confirmed the presence of PCBs in transformers on the site and asbestoscontaining construction materials in some buildings. The transformers have been catalogued with respect to PCB concentration and are monitored by the responsible electric company. The only building in which asbestos was identified as being in a friable condition is no longer used, ensuring the health of site workers; abatement measures were recommended in the asbestos survey. No further PA/IRP actions are recommended for these sites. 


\subsubsection{Unauthorized Disp sal of Waste}

Of concern are two unauthorized waste disposal areas on TXARNG property. Both disposal areas are within drainage pathways feeding Lake Mineral Wells, to the south of Fort Wolters. Lake Mineral Wells is the source of drinking water for the surrounding population. The disposal area in the northern portion of the TXARNG property contains household-type waste probably left on the site by a trespassing civilian. Cleanup of that small disposal area is recommended primarily to discourage continued trespassing and discarding of waste on the property. No health hazard or risk to Lake Mineral Wells is suspected. The second, much larger disposal area contains metal debris and other waste strewn along an area approximately $300 \mathrm{ft}$ long and $10 \mathrm{ft}$ wide (as estimated from the air). Close inspection of the disposal area is recommended to characterize the waste content. If the waste is determined to be hazardous (for example, containing a substantial number of containers or drums for chemicals or petroleum products), sampling within the disposal area and along the drainage pathway downgradient from it is recommended. Such sampling would include collection of near-surface and subsurface soil samples. If drainage into Rock Creek (which feeds Lake Mineral Wells) or a tributary is evident, surface water sampling at that drainage location is recommended. The objective of this limited soil and water sampling effort would be to determine whether contamination is present at a level that would place the downgradient surface water resources at risk. 


\section{References}

Adams, 1976, Fort Wolters WETEP No. 2 Addition, Construction plans for modification of the former Nike missile launch area, prepared by Moffatt D. Adams, Architect, Dallas, Texas, for Texas Army National Guard, June 15.

Bennett, J.W., 1985, Request for Texas Department of Health Identification Number for Solid Waste Management Related Activities, Letter from Bennett, Supply Management Officer, Texas Army National Guard, to J. Martin, Texas Department of Health, Bureau of Solid Waste Management, February 14.

Buckner, H.D., and W.J. Shelby, 1991, Water Resources Data, Texas, Water Year 1990; Volume 2, San Jacinto River Basin, Brazos River Basin, San Bernard River Basin, and Intervening Coastal Basins, Report USC,S/WRD/HD-91-295, U.S. Geological Survey, Water Resources Division, Austin, Texas, June.

BWR, 1990, Construction Plans for Aboveground Fuel Storage Tank and Dispensing System, Fort Wolters, Texas, Bucher, Willis \& Ratliff, Consulting Engineers, Planners and Architects, August 29.

Cain, J.P., 1986, Co-Use Lease DACA63-1-83-0538, Texas State Rifle Association, Texas Army National Guard Facility, Fort Wolters, Texas, Letter from Cain, Chief, Real Estate Division, Texas Army National Guard, to D. Beham, Executive Secretary, Texas State Rifle Association, Dallas, Texas, February 27.

Cottrell, M.B., 1979, Renewal of the Texas National Guard License DACA63-3-75-0023, Fort Wolters, Texas, Letter from Cottrell, Chief, Real Estate Division, Department of the Army, Corps of Engineers, Fort Worth District, to The Adjutant General, Texas, May 15.

Dennis, C.B., 1993, unpublished site reconnaissance and interview notes gathered for the preliminary assessment of Fort Jacob F. Wolters, Mineral Wells, Texas, February.

DHUD, 1977, 100-Year Flood Hazard Boundary Map, Fort Wolters, Mineral Wells, Texas, U.S. Department of Housing and Urban Development, December 27. 
DOT, 1982, General Highway Map - Palo Pinto and Parker Counties, U.S. Department of Transportation, Texas Department of Highways and Public Transportation, June 1.

Duffin, G.L., and B.E. Beynon, 1992, Evaluation of Water Resources in Parts of the Rolling Prairies Region of North-Central Texas, Report 337, Texas Water Development Board, Austin, Texas, March.

ESE, 1984, Historical Overview of the Nike Missile System, Report DRXTH-AS-IA-83016, prepared by Environmental Science and Engineering, Inc., Gainesville, Florida, for the U.S. Army Toxic and Hazardous Materials Agency, Aberdeen Proving Ground, Maryland, December.

FHHH, 1988, Military Vehicle Wash Rack at Fort Wolters UTES \#2, Mineral Wells, Texas, Job 88057, Fisher, Hagood, Hamilton \& Heil, Consulting Engineers, Round Rock, Texas, August 15.

Gore, H.G., and J.M. Reagan, principal investigators, 1989, Federal Aid in Wildlife Restoration Act - Texas, Texas Parks and Wildlife Department, Federal Aid Project W-109-R-12, August 15.

Greenwade, J.M., J.D. Kelley, and H.W. Hyde, 1977, Soil Survey of Parker County, Texas, U.S. Department of Agriculture, Soil Conservation Service, June.

Hall, C.J., 1988, Master Plan for Fort Wolters, State Territory Environmental Specialist, Texas Army National Guard, October 12.

Heath, R.C., 1989, Basic Ground-Water Hydrology, Water-Supply Paper 2220, U.S. Geological Survey, Books and Open-Reports Section, Federal Center, Denver, Colorado.

Jorgensen, D.G., J. Downey, A.R. Dutton, and R.W. Maclay, 1988, "Region 16, Central Nonglaciated Plains," Chapter 19 in W. Black, J.S. Rosenshein, and P.R. Seaber, editors, Hydrogeology: The Geology of North America, Vol. O-2, Geological Society of America, Boulder, Colorado.

Larkin, T.J., and G.W. Bomar, 1983, Climatic Atlas of Texas, Report LP-192, Texas Dep rtment of Water Resources, Austin, Texas, December. 
LETC, 1986, Investigation of Former Nike Missile Sites for Potential Toxic and Hazardous Waste Contamination, Volumes 1 and 2, prepared by Law Engineering Testing Company, LESGovernment Services Division, Atlanta, Georgia, for the U.S. Army Corps of Engineers, Huntsville Division, under Contract DACA87-85-C-0104, March.

NGB, 1978, Environmental Assessment for an Aerial Drop Zone at Fort Wolters Army National Guard Training Site, Mineral Wells, Texas, Departments of the Army and the Air Force, National Guard Bureau, Washington, D.C., September.

NGB, 1986, Sizing of TXARNG Training Site - Camp Wolters, Texas, Memorandum from Col. J.R. D'Araujo, Jr., Chief, Army Organization and Training Division, to The Adjutant General, Texas, Departments of the Army and Air Force, National Guard Bureau, Falls Church, Virginia, July 21.

NGB, 1988, Army National Guard Facility Inventory and Stationing Plan (FISP), U.S. Army National Guard Bureau, Aberdeen, Maryland, January.

Nordstrom, P.L., 1982, Occurrence, Availability, and Chemical Quality of Ground Water in the Cretaceous Aquifers of North-Central Texas, two volumes, Report 269, Texas Department of Water Resources, Austin, Texas, April.

Rand McNally, 1992, Rand McNally 1992 Atlas, Rand McNally and Company, Chicago, Illinois.

Shields, H., 1992, Mineral Wells - PCB Inquiry, Fort Wolters Industrial Park, Letter from Shields, District Manager, TU Electric Company, Mineral Wells, Texas, to Maj. G.L. Huffman, Texas Army National Guard, February 27.

Starr, Jr., J., 1975, Ceremony at Fort Wolters, 11 April 75, Memorandum from LTC Starr, Chiet, Facilities and Engineering Branch, Texas Army National Guard, to M.G. Bishop, about program of the ceremony transferring title of federal property at Fort Wolters to state and local agencies, April 17.

STS, 1991, Correspondence describing analytical results for Fort Wolters Nike site samples 1, 2, and 3, including the chain-of-custody record for sample delivery, Sizemore Technical Services, Inc., Round Rock, Texas, April 22. 
TDH, 1986, Water bacteriology report of well samples collected at Fort Wolters Helicopter Stage Fields 1 and 2, Texas Department of Health, Bureau of Laboratories, Fort Worth City Health Department Laboratories, August 14.

Tryce, D., 1992, Facsimile to Major Tryce, Texas Army National Guard, from M.S. Catron, EmTech Environmental Services, Inc., Fort Worth, Texas, containing data summary table of PCB analysis of TXARNG-owned transformers at Fort Wolters training site, December 23.

TWC, 1986, Notification for Underground Storage Tanks, Texas Water Commission, Underground Storage Tank Program, Austin, Texas, April 14.

TWC, 1993, Records of wells filed by the Texas Water Commission with the state of Texas through the Texas Water Well Drillers Board, Austin, Texas.

TXARNG, 1987, Spill Prevention, Control and Countermeasure Plan for Fort Wolters UTES \#2, Texas Army National Guard, November 10.

TXARNG, 1991, Hazardous Materials Inventory Checklist, Fort Wolters Training Site, Mineral Wells, Texas, Texas Army National Guard, Inventoried by R.H. Dietz, Responsible Officer Maj. G.L. Huffman, July 11.

TXARNG, 1992a, Out-Briefing Summary, Environmental Compliance Assessment Study, UTES 2, Mineral Wells Facility, Texas Army National Guard, March 12.

TXARNG, 1992b, Out-Briefing Summary, Environmental Contamination Assessment Study, Texas Army National Guard, E. Tambini and D. Dischner, team members, March 13.

USACE, 1958, Nike-Hercules Facilities - Mineral Wells Site Launching Area Layout and Dimension Plan, Dallas-Fort Worth Defense Area, Texas, Contract DA-41-443-ENG-5368, U.S. Army Corps of Engineers, Fort Worth District, August 1.

USACE, 1970, General Site Map - Fort Wolters, Mineral Wells, Texas, File GM-100-2, U.S. Army Corps of Engineers, Fort Worth District, March. 
USACE, 1978, Survey Grid Map - Mineral Wells, Texas, Sheet 63491, Series V782, Army Map Service, U.S. Army Corps of Engineers, Washington, D.C.

USACE, 1993, Asbestos Survey - Fort Wolters, Mineral Wells, Texas, prepared by Geo-Marine, Inc., Plano, Texas, for U.S. Army Corps of Engineers, Fort Worth District, Contract DACA63-90-D-0061, February.

USGS, 1959a, Topographic Map - Mineral Wells, Texas, U.S. Geological Survey, 15 Minute Topographic Map Series, N3245-W9800/15.

USGS, 1959b, Topographic Map - Weatherford, Texas, U.S. Geological Survey, 15 Minute Topographic Map Series, N3245-W9745/15.

Whisenhunt, B.J., 1987, Survey, Fort Wolters National Guard Facility, Mineral Wells, Texas, Memorandum from Col. Whisenhunt, Director, Facilities and Engineering, Texas Army National Guard, to the Department of the Army, Fort Worth District Corps of Engineers, Fort Worth, Texas, November 18. 
PA for Fort Jacob F. Wolters

65

Appendix:

Interview Information 


\section{Appendix:}

Interview Information

\section{Individuals Interviewed}

Environmental Officer

Texas Army National Guard

Camp Mabry

Austin, Texas

Construction Inspector (retired)

Texas Army National Guard

Camp Mabry

Austin, Texas

Maintenance Foreman

Texas Army National Guard

Fort Wolters

Mineral Wells, Texas

Texas Water Commission, Water Well Registry

Austin, Texas

Geologist

Texas Water Development Board

Austin, Texas

\section{Argonne Investigators}

Clyde Dennis

(708) 252-5999

George Hildebrandt

(708) 252-4991

Candace Rose

(708) 252-3499 

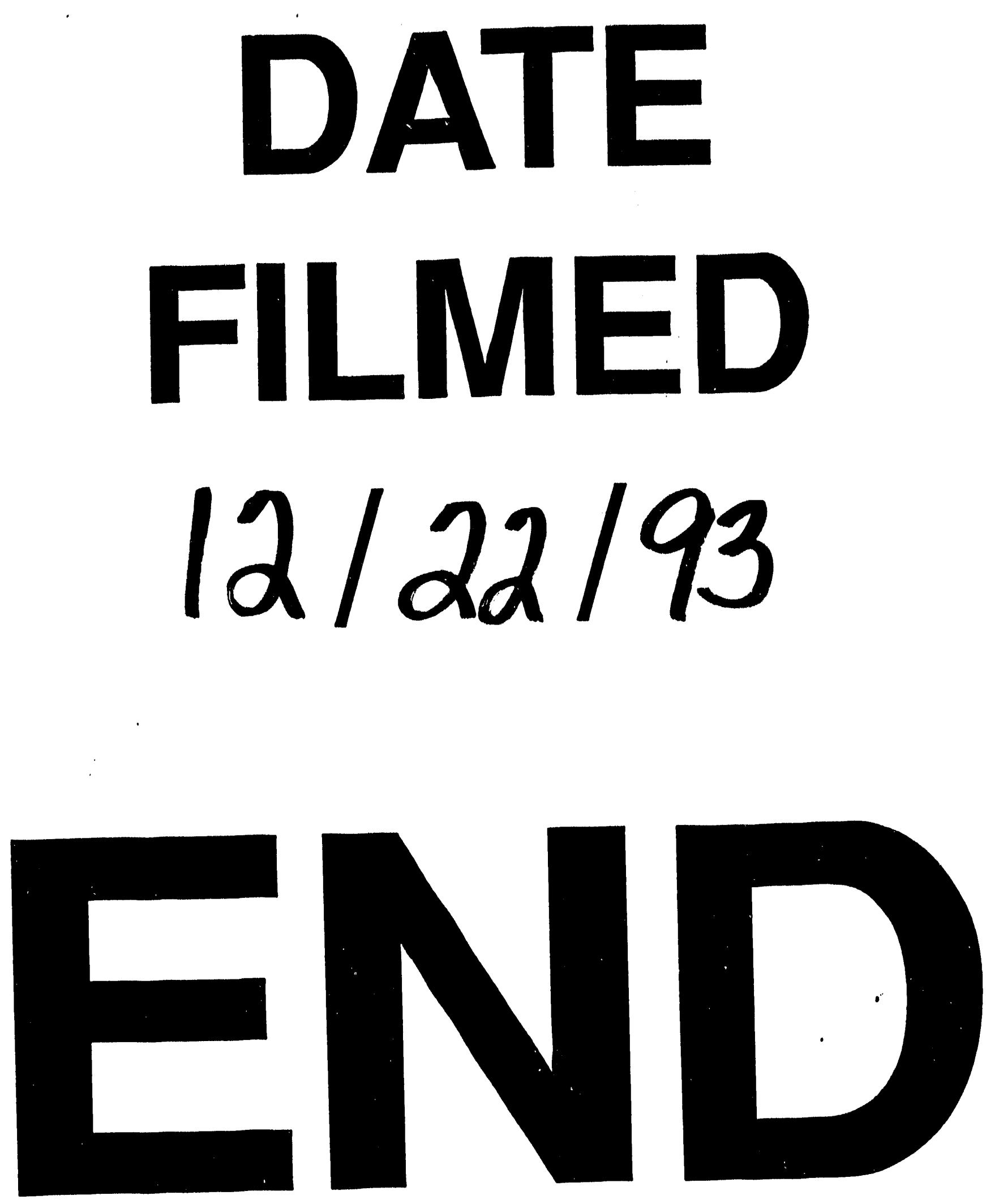
